Florida International University FIU Digital Commons

FIU Electronic Theses and Dissertations

University Graduate School

$4-1-2004$

\title{
Parallel relationships, architecture and water : the urban spa
}

Tobi Aycock

Florida International University

DOI: $10.25148 /$ etd.FI14032383

Follow this and additional works at: https://digitalcommons.fiu.edu/etd

Part of the Architecture Commons

\section{Recommended Citation}

Aycock, Tobi, "Parallel relationships, architecture and water : the urban spa" (2004). FIU Electronic Theses and Dissertations. 1358. https://digitalcommons.fiu.edu/etd/1358

This work is brought to you for free and open access by the University Graduate School at FIU Digital Commons. It has been accepted for inclusion in FIU Electronic Theses and Dissertations by an authorized administrator of FIU Digital Commons. For more information, please contact dcc@fiu.edu. 
FLORIDA INTERNATIONAL UNIVERSITY

Miami, Florida

PARALLEL RELATIONSHIPS, ARCHITECTURE AND WATER:

THE URBAN SPA

A thesis submitted in partial fulfillment of the

requirements for the degree of

MASTER OF ARCHITECTURE

by

Tobi Aycock

2004 
To: Dean Juan Antonio Bueno

School of Architecture

This thesis, written by Tobi Aycock, and entitled Parallel Relationships, Architecture and Water: The Urban Spa, having been approved in respect to style and intellectual content, is referred to you for judgment.

We have read this thesis and recommend that it be approved.

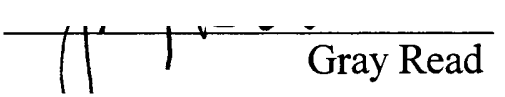

Gisela Lopez-Mata

William McMinn, Major Professor

Date of Defense: April 1, 2004

The thesis of Tobi Aycock is approved.

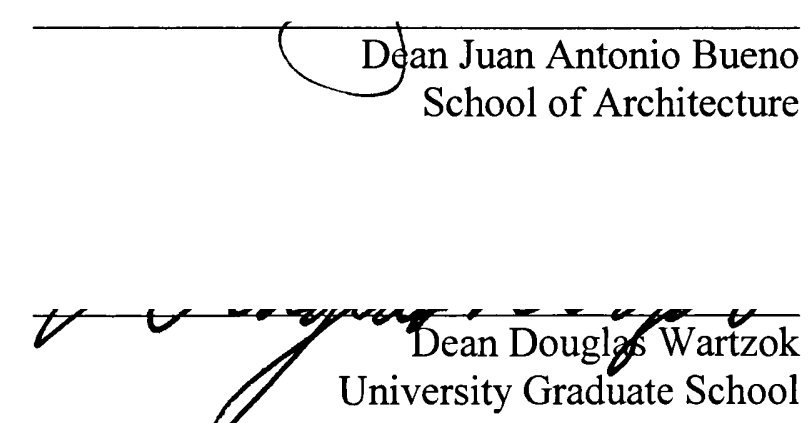

Florida International University, 2004 
(C) Copyright 2004 by Tobi Aycock

All rights reserved. 


\section{ABSTRACT OF THE THESIS}

\section{PARALLEL RELATIONSHIPS, ARCHITECTURE AND WATER: THE URBAN SPA}

by

Tobi Aycock

Florida International University, 2004

Miami, Florida

Professor William McMinn, Major Professor

This thesis explores the relationship of architecture and water through the design of an urban spa that offers both a bodily and a poetic experience of water. Research included investigation of recent architectural projects that enhance and order the view, sound, and touch of water as well as projects that integrate fountains, showers and reflecting pools into the experience of a building.

In the design of the spa, the movement of water was based metaphorically on the natural water cycle: evaporation, condensation and collection of water in pools. The building presents fountains, rivulets, and pools in a descending sequence that represents the natural flow of water. The temperature of water and the activities of the spa follow the same descending sequence, progressing from a warm water bath at the top of the building to cool swimming pool at the plaza level in a contemporary interpretation of the experience of a Roman Bath. 
INTRODUCTION

II. PROJECT DESCRIPTION

The Urban Spa

The Urban Spa

The Water Cycle ........

Architecture and Water.

Project Narrative

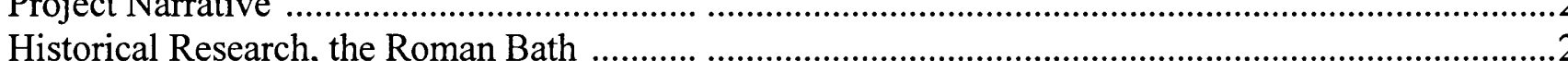

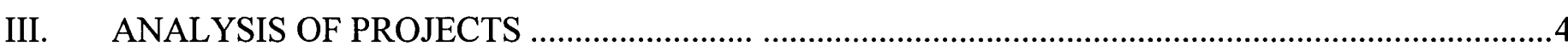

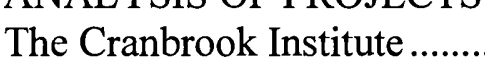

Whitney Water Works

The Okavango Delta Spa

Poolhouse........

Venetian Pool...

IV. SITE ANALYSIS .

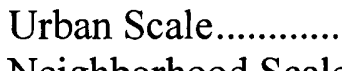

Neighborhood Scale...

Hyde Park Market Site.

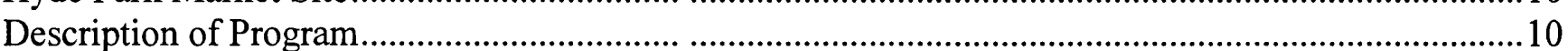

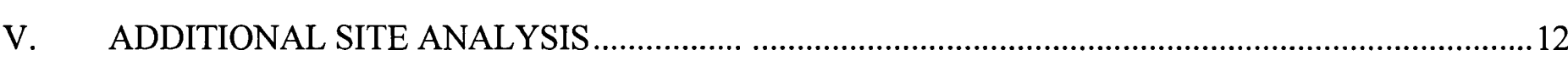

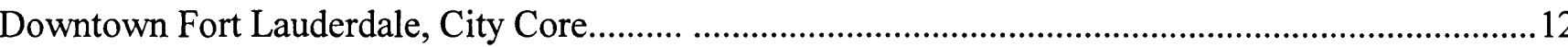

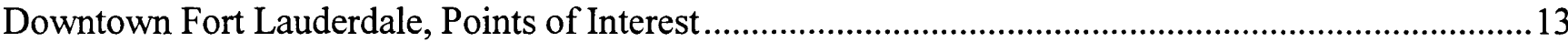

Site Analysis, Problems

Analytical Diagrams

VI. DESIGN DEVELOPMENT, CONCEPTUAL INSPIRATION AND PRECEDENTS ..........................17

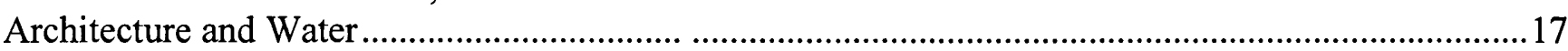

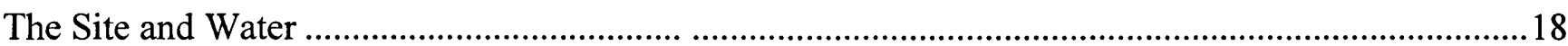

The Water Cycle

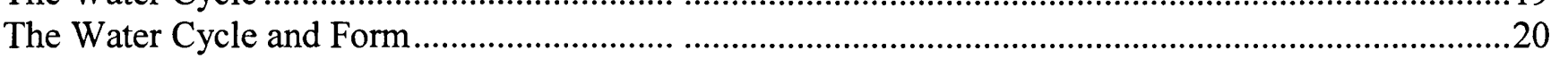

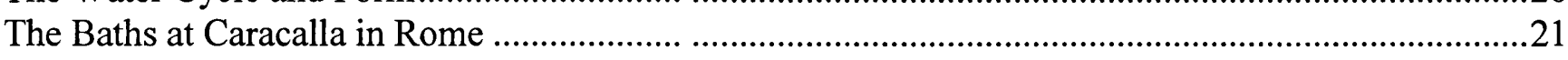

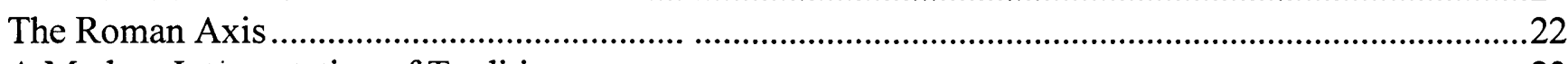

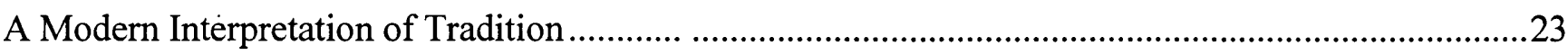

Influence Fountains .

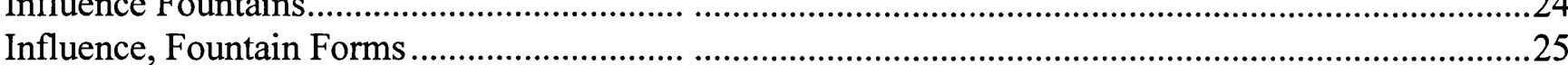

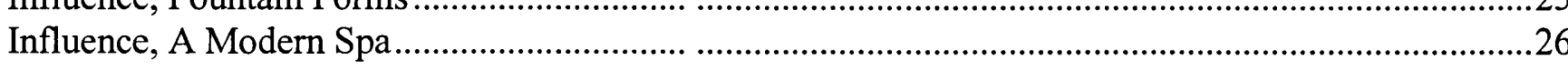

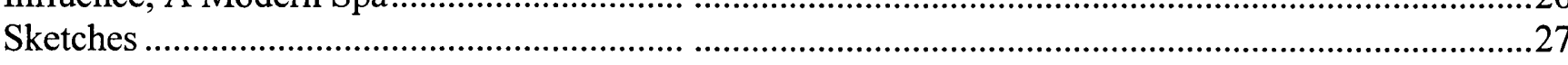

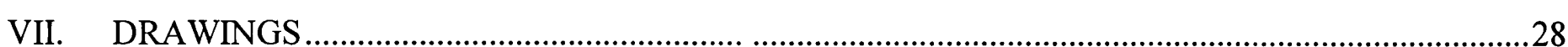


Site Plan, Urban Perspective

Site Schematic and Figure Ground Map.............29

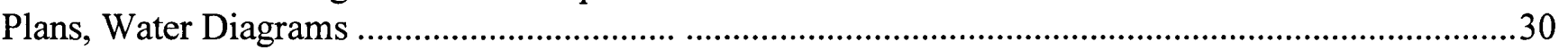

Floor Plan, Ground Level

Floor Plan, Spa Level One....

Floor Plan, Spa Level Two

Floor Plan, Spa Level Three

Floor Plan, Roof Level.

North Elevation, Las Olas Boulevar

South Elevation, New River

East Elevation...

West Elevation.

(1)

Longitudinal Section, Water Diagram

Short Section, Water Diagram

Detailed Wall Section, Stair Enclosure and W

Sketch Model

Concept Model, Computer Rendering

Computer Modeled Rendering

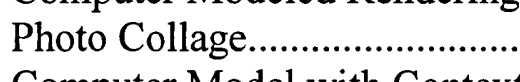

Computer Model with Context

VIII. CONCLUSION 
1. Conceptual Diagram

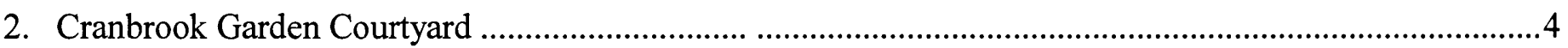

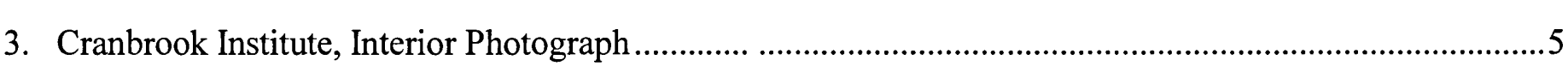

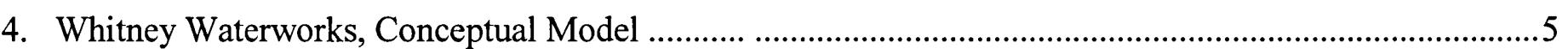

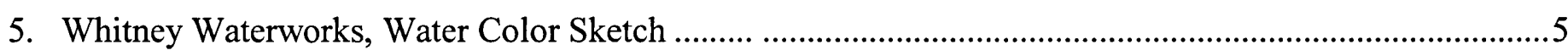

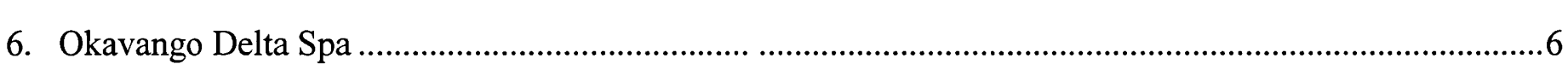

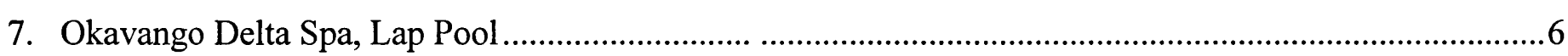

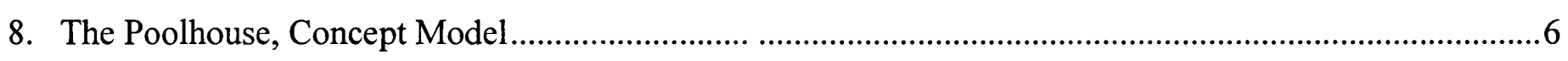

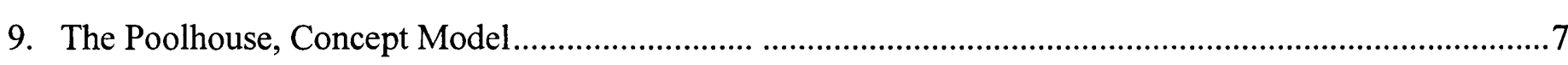

10. Downtown Fort Lauderdale, Hyde Park Market Site ………...................................................................

11. Downtown Fort Lauderdale, Districts and Building Use Diagrams ...................................................

12. Las Olas Corridor and Riverwalk Use Cycle Diagram ...............................................................................

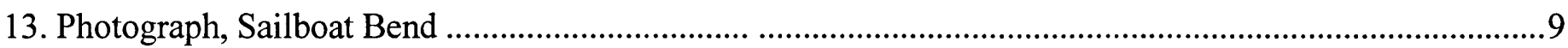

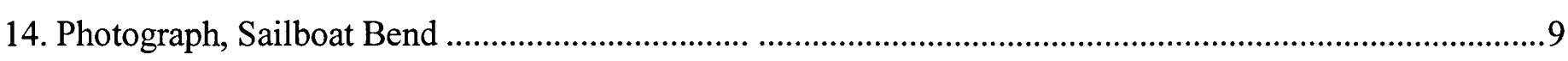

15. Photograph, Downtown Himmarshee District..................................................................................9

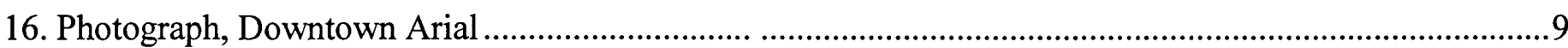

17. Photograph, Huizenga Plaza and Museum ....................................................................................

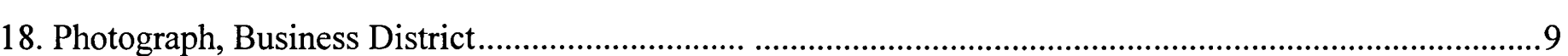

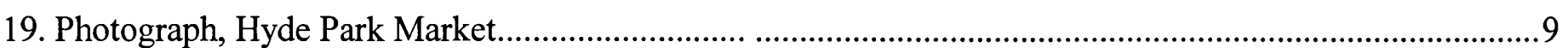

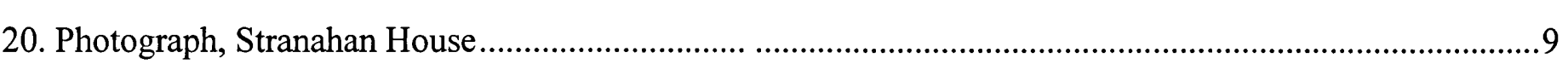

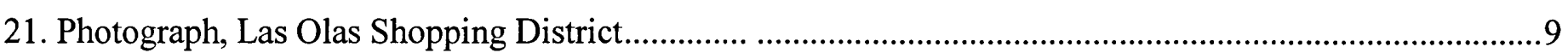


22. Photograph, Las Olas Shopping District

23. Photograph, Riverwalk

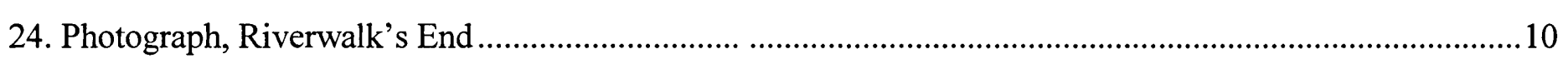

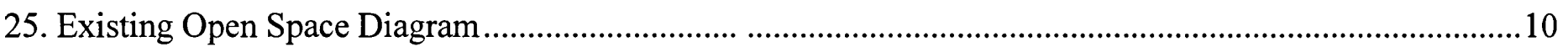

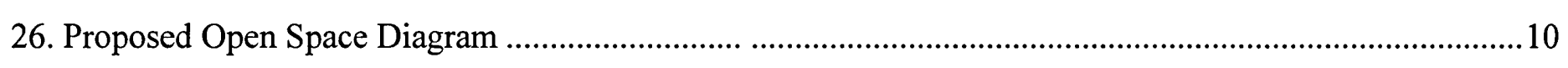

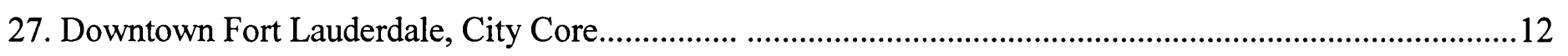

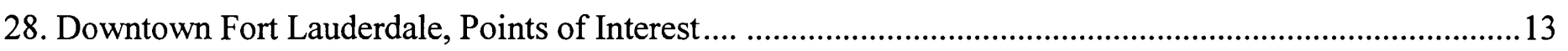

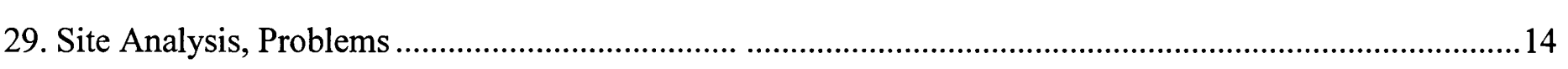

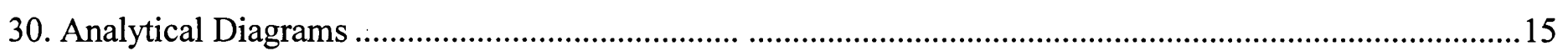

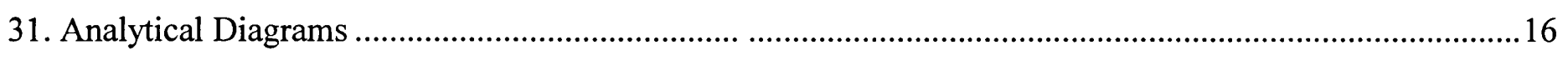

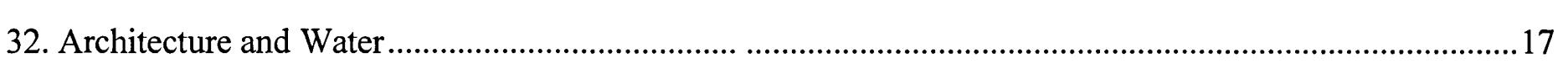

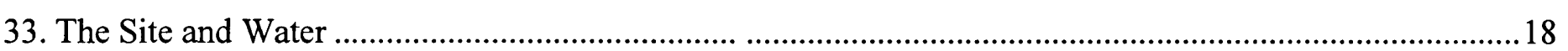

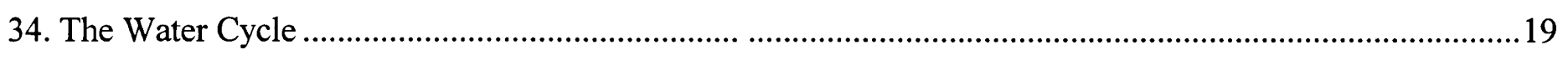

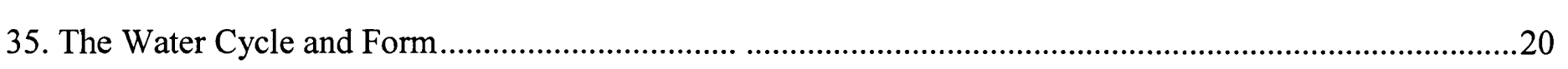

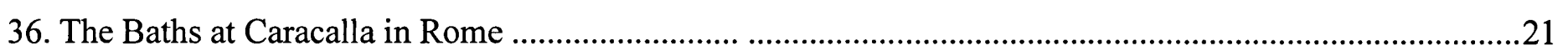

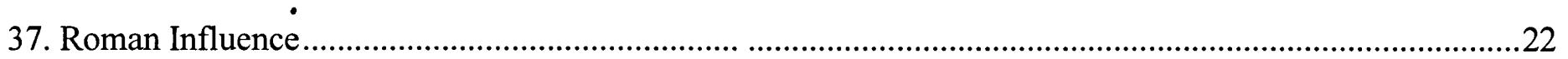

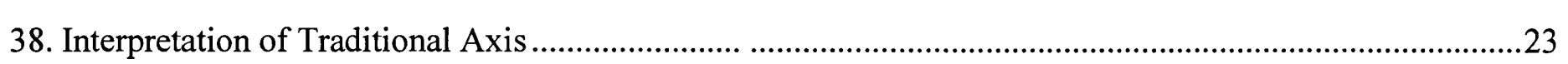

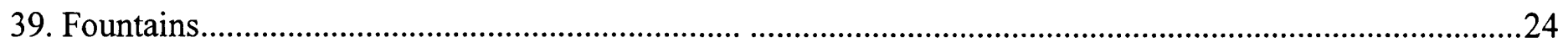

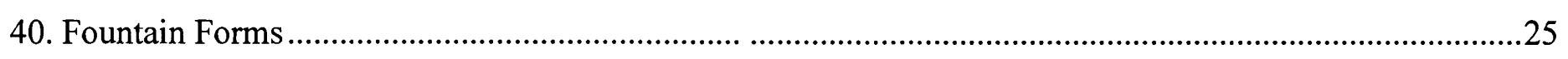

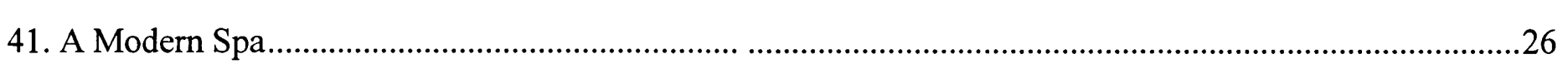

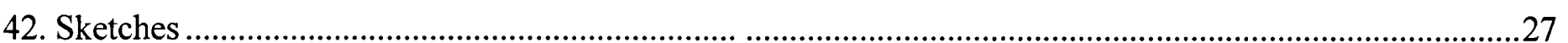

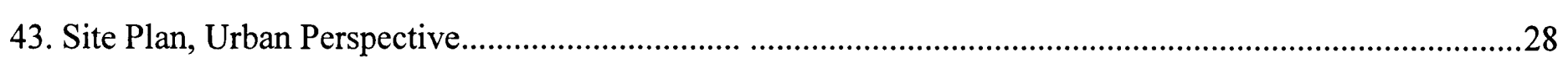

44. Site Schematic and Figure Ground Map................................................................................2 
45. Plans, Water Diagrams

46. Floor Plan, Ground Level

47. Floor Plan, Spa Level 1

48. Floor Plan, Spa Level 2.

49. Floor Plan, Spa Level 3.

50. Floor Plan, Roof Level

51. North Elevation, Las Olas Boulevard

52. South Elevation, New River

53. East Elevation

54. West Elevation.

55. Longitudinal Section, Water Diagram

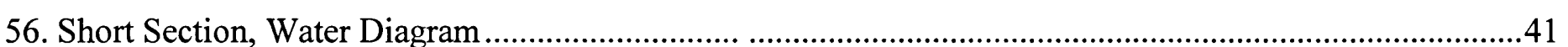

57. Detailed Wall Section, Stair Enclosure and Wall of Rain .........................................................................42

58. Sketch Model.....

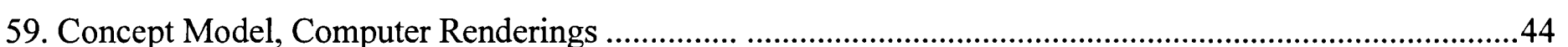

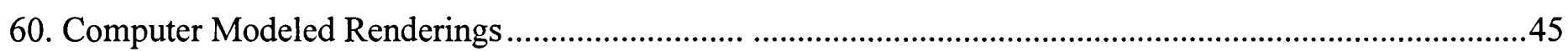

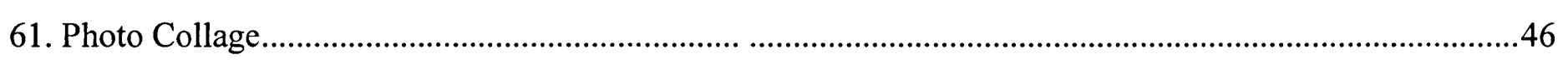

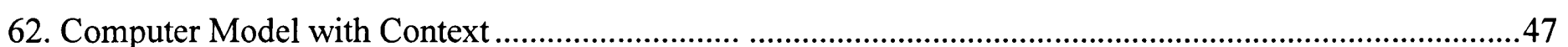




\section{INTRODUCTION}

"More than anything else water is a source of life and the great symbol of life. All life depends on water; nothing escapes its influence, and nothing lives without it."

\section{Charles W. Moore ${ }^{[1]}$}

Through architecture, we capture and understand the qualities of water with all of our senses Water has been used in design since antiquity as a symbol of life as well as a something at first indispensable and then disposable, that eternally returns. The way in which we use water in design demonstrates much more than our technical capabilities; it also reflects our traditional and holistic views of our relationship with the environment. All buildings engage water in their plumbing and drainage systems, and some render these to be beautiful. Design can enhance and organize the view, sound and physical touch of water; fountains, showers and reflecting pools offer water as a sensuous element integrated into the experience of a building. My project explores the relationship of architecture and water through the design of an urban spa that offers both a bodily and a poetic experience of water.

The movement of water in the spa is based on the stages of the natural water cycle as it is evaporated from the ocean, condenses in clouds, rains down, and is collected in streams and rivers to return to the ocean. The movement of people through the spa is ordered by the sequence of activities established by the Roman Bath: by the temperatures of water. The levels of the spa are defined by the relationship between the activity and temperature of the water, using the natural water cycle as a metaphor.

\section{PROJECT DESCRIPTION}

\section{THE URBAN SPA}

How can architecture offer a sensuous interpretation of our water cycle?

Through architectural design, this project will help people understand and appreciate water in South Florida, both as a valuable natural environment and as a sensuous part of life. The project explores the architectural presentation of water and develops a symbolic relationship between the natural cycle of water and its cultural uses and meanings. The design introduces people to the water cycle as a poetic natural phenomenon. My thesis project includes a public square, a public pool and a spa designed to symbolize and celebrate the movement of water in its natural cycle. Located along the New River in downtown Fort Lauderdale, it reclaims an area of the city for public use and provides a connection between the urban components of the city and the river.

Inspired by the Roman bathhouse, the Urban Spa provides the setting for people to enjoy the sensuous qualities of water. The project uses the water cycle as a metaphor to allow visitors a chance to experience the moods of water. Unlike many building types, a spa or bathhouse generates a body and mind experience that is initiated by personal and direct contact with water. Through design water becomes something more than a wet substance circulating through pipes: it is essential to life both physically and poetically.

\section{THE WATER CYCLE}

The water cycle is a series of movements of water above, on and below the surface of the earth. It consists of four stages: storage, evaporation, precipitation and runoff. Water is stored in aquifers; in rivers, lakes and oceans; and in glaciers. It evaporates from the surface, forms clouds, and returns in the form of rain or snow. It then travels to the sea or reevaporates repeating its process. Nature recycles our water continuously. Very little water has been lost or created in the past billion years. ${ }^{[2]}$ 


\section{ARCHITECTURE AND WATER}

Architect Charles Moore interprets the four stages of the water cycle in architecture as fountains, rivers, pools and oceans. I use interpretations in my project to explore several facets of the relationship between water and architecture. In my project, the fountain is analogous with rain and the regeneration of life, the beginning of the cycle, and will mark the beginning of the bathing sequence of the spa. Historically, fountains such as Bernini's Fountain of the Four Rivers in Rome (1648-51) signify important places and beginnings. From its source, the rain, a spring, or in my project the aquifer, rivers carry water across the land to the sea. A rivulet flows between the spa and the pool, suggesting streams and rivers that collect and carry rain. During its travels, water cools both the earth and the air by evaporation. Lakes collect and store water. In architecture, lakes are expressed as pools bringing the reflective or calming qualities of water into buildings. In my project, a pool will collect water from the rivulet. The Ocean is a vast and infinite space that suggests infinite continuity. Infinity pools are designed in reference to this analogy. The Malibu Infinity Pool (1991) designed by landscape architect Barry Beer is located in Malibu, California. The pool is designed to merge the coastline with the Pacific Ocean extending the site to the line of the horizon. In my project the New River may represent the ocean, and the exercise pool will merge the site with the river. The natural processes, functions and states of water are suggested by the design as the water moves from one stage to the next. The building plumbing and cooling systems use the cool water drawn from the aquifer to tie the water elements of the building and its program together as a gesture of the continuity of the water cycle. ${ }^{[3][4][5]}$

\section{PROJECT NARRATIVE}

My design uses the water cycle as an architectural narrative for the spa. Figure 1 is a conceptual diagram that represents the intentions of the project: how the stages of the water cycle are organized, and how people move through the spaces. The four conditions of water represent the stages of the water cycle (fountains, rivers, pools and oceans) and illustrate how water travels in the natural environment. The project unfolds in levels defined by the temperature of the water and the sequence of activities, a concept derived from both the water cycle and the Roman bathhouse. The top level is reserved for hot water and exercise. The water of the aquifer is drawn up and merges with the collected rain. It is warmed by the sun and begins its descent to the hot bath and warm room. The water of the aquifer is presented as a cold water fountain within the hot bath. The middle of the sequence holds warm water baths and massage. The warm room (sauna), steam and Vichy showers offer a 'warm' experience. The first level of the spa is dedicated to the cold pool.

Below the spa, the experience and activities are more public in nature. As visitors ascend, a more private experience evolves around the moods and temperatures of water combined with the program of a modern spa.

\section{HISTORICAL RESEARCH, THE ROMAN BATH}

The history and tradition associated with the Roman bath have a strong influence on this project. In their time, the Roman baths represented "the ideal Roman way of life ${ }^{[6] "}$. They incorporated exercise, libraries, lecture or recital halls, gardens, entertainment and food in addition to formal bathing rituals. Bath houses generated an environment well suited for gracious social interaction. ${ }^{[6]}$ 
Parallel Relationships, Architecture and Water:

The Urban Spa

Conceptual Diagram:

of water and people

through the spa.

\section{Water as a real phenomenon, water as a
sensual bodily experience, \\ sensual bodily experience,
water as a poetic metaphor.}

\section{water as a poetic metaphor...}

Architectural Narrative

Water Cycle

river
pool

Historical

Roman Bath

Roman Bat

hot bath
warm room

cold pool
social stimulus

Interpretive

Modern Spa
exercise, medit

exercise, meditation
water therapy, massag
pool

pool
since of community pool

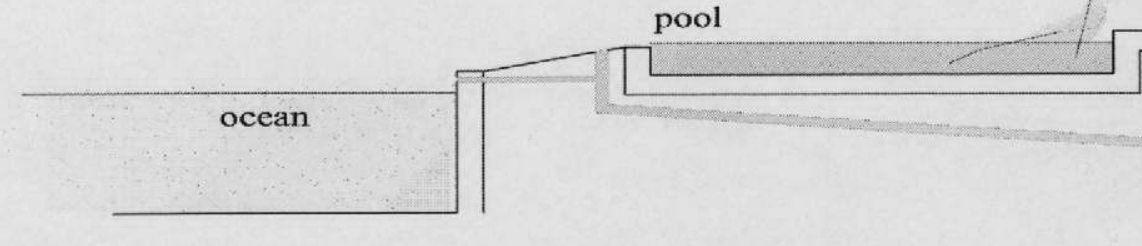

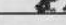

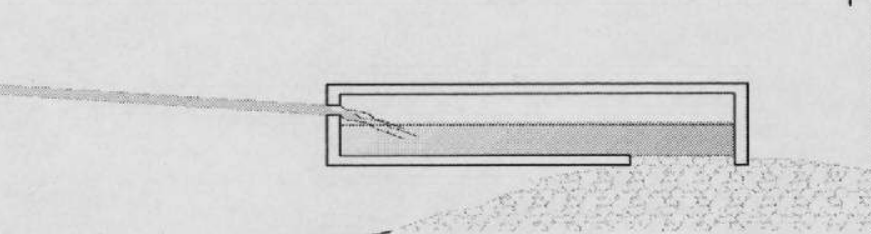

aquifer

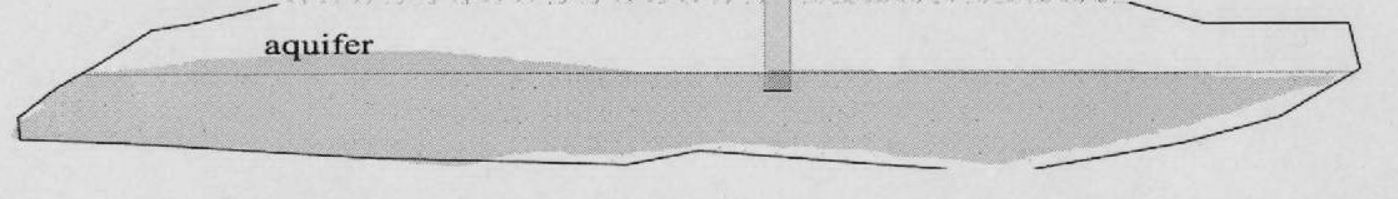

\section{Figure 1 Conceptual Diagran}

Traditionally, The Roman bath includes the caldarium or hot bath, a tepidarium, a warm room with heated walls and floors and sometimes a pool; and a frigidarium or cold pool. When visiting a bath house, most patrons followed a ritual sequence of bathing. After exercising and/or an oil massage, the 'bathing proper' began in the warm room. The warm room can be interpreted as a sauna today. They next visited the hot baths. The hot baths included a waist-high fountain of cold water called a labrum adjacent to the bath. The cold water of the fountain was used to splash the face and neck for

refreshment. After the bath, bathers often proceeded back to the warm room before concluding the sequence with a plunge in the invigorating cold pool.
PRIVATE

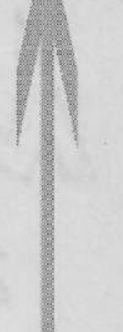

PUBLIC

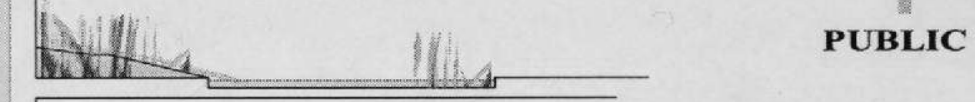


In plan, the principle rooms of the Roman bathhouse are designed along an axis with the tepidarium in the center. In later designs, a large pool for exercising was included in the program: the natatio. The Baths of Caracalla, Rome (AD 212-216) is one of the best examples we have of a fully developed thermae. Secondary spaces of the baths include rooms that provide moist steam, dry heat (like a sauna) and massages with various types of oils. The preliminary program for my project descends from the Roman bath. It provides the setting in which bodies will experience the qualities of water in its various temperatures, as hot, warm and cold sensations. ${ }^{[7][8]}$.

\section{ANALYSIS OF PROJECTS}

I have looked at several similar projects, including the addition to the Cranbrook Institute of Science and Whitney Water Works by architect Steven Holl, the Okavango Delta Spa and the Poolhouse in Sagaponac by architect Lindy Roy. These 4 projects have successfully articulated the idea that water is something more.

\section{THE CRANBROOK INSTITUTE, 1992-1998}

In the garden courtyard of the Cranbrook Institute, the story of water is told by the three states of water: ice, liquid and vapor. The garden courtyard slopes and folds, subtly connecting it to the topography of the landscape and the campus. Visitors experience water in its three states as they walk through the spaces. The metaphors are tied to the building's circulation. In the design of the garden, Holl demonstrates water as ice in the form of a welded-steel House of Ice. In the winter, steam rises through the floor and ice forms on the steel teardrop shaped frame. Tiers of pools are used to represent water in its liquid state. As one passes from the lobby to the garden, a slender pool flows over a glass bottom and projects patterns of waves into the space below. Glass of different types and opacities are used throughout the project achieving similar effects. The entrance from the garden is the concrete
House of Vapor. In this small room visitors experience water as vapor rising from beneath the perforated floor. In my project the progress of the water cycle, the narrative, is tied to circulation of both water and people through the spa. Light, water and glass are used to accentuate this connection. ${ }^{[9]}$

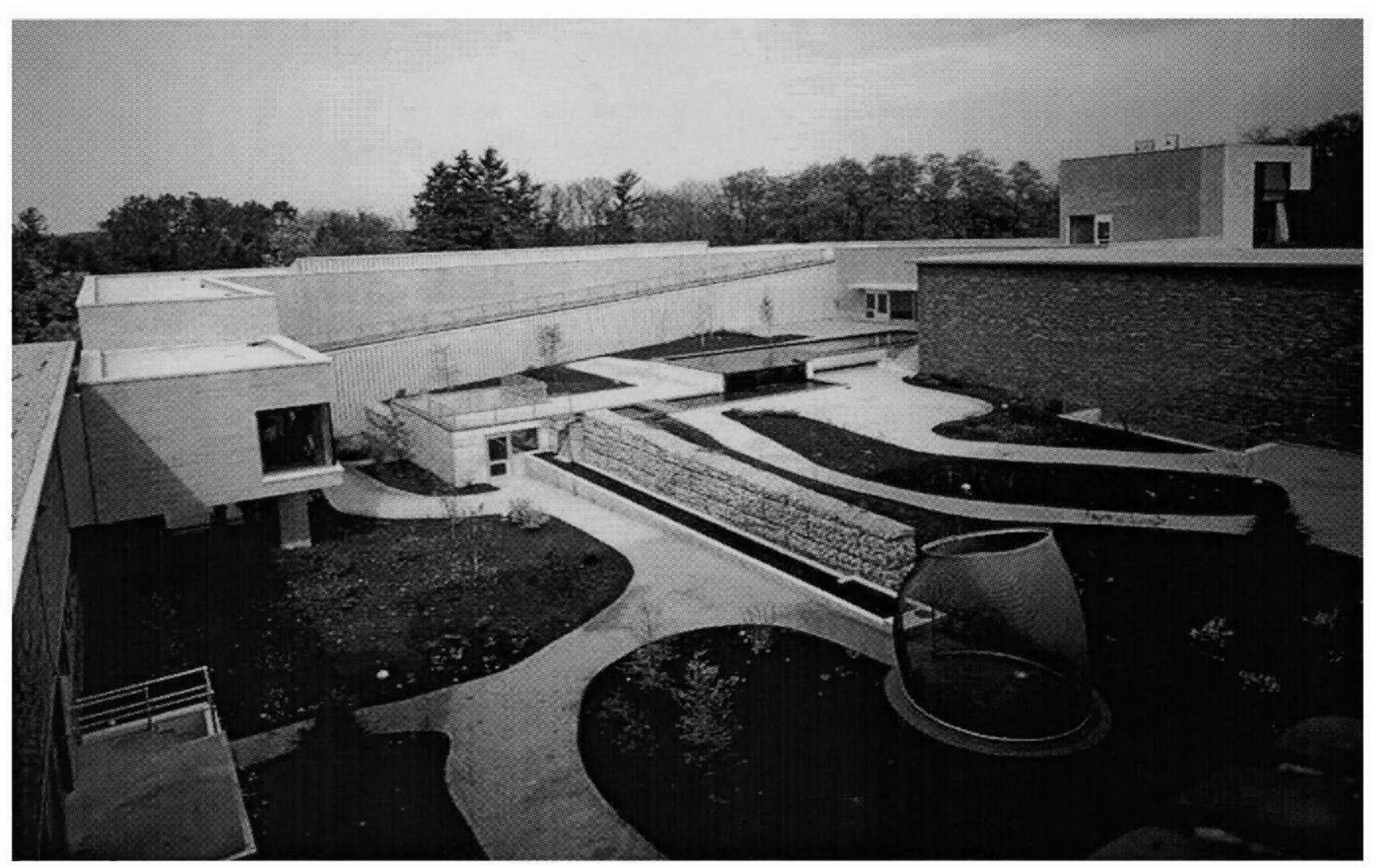

Figure 2 Cranbrook Institute, garden courtyard. 


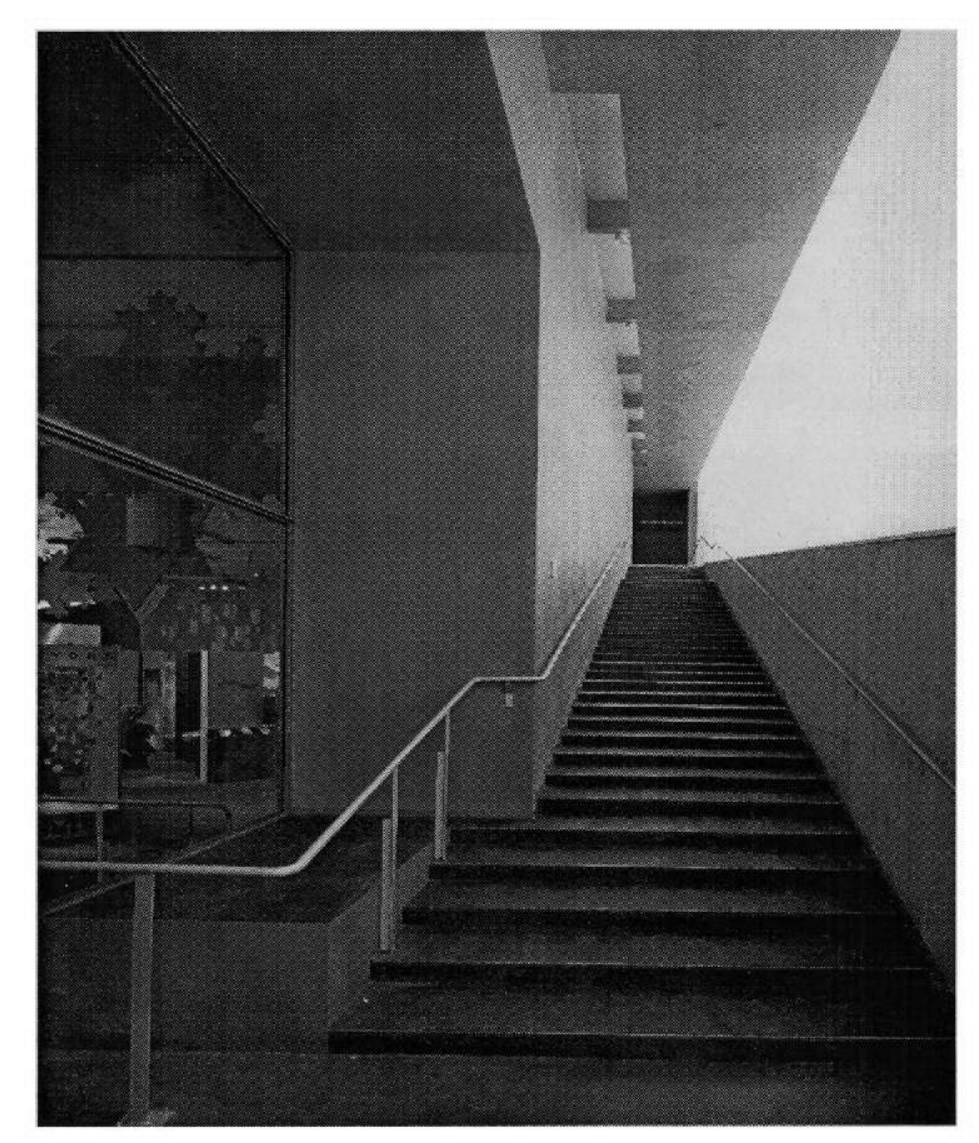

Figure 3 Cranbrook Institute, interior photograph.

\section{WHITNEY WATERWORKS PARK, 1998-}

Whitney Waterworks is a water treatment facility and public park now in the process of construction. The park is in Hamden Connecticut. It is being built on the historic site of the Old New Haven Treatment Plant. Architect Steven Holl designed the park in six parts, each analogous to a step in the water treatment process. The six water treatment phases are: rapid mix (high turbulence),

flocculation (wave agitation), dissolved air floatation, ozonation (bubbling), deep bed GAF filtration, and clean water storage. A field of wild moss represents the process of "ozonation bubbling." The field is covered with a structure containing skylights he calls "bubble lenses." Holl represents rapid mixing and high turbulence as "agitated grass mounds." The grass hills have small streams cutting through

them and are incorporated into a section of the parks landscape. Visitors are reminded of the plant below as steel pipes release steam through the surface. The steel clad administration building provides facilities for educating the public on water issues. Its form appears almost liquid as it rises from beneath the grounds surface. Inside, Holl combines water and light in vapor, he creates a rainbow of mist using spray fountains and uses light to project the patterns of water onto stone for visitors to visually experience. $^{[10]}$

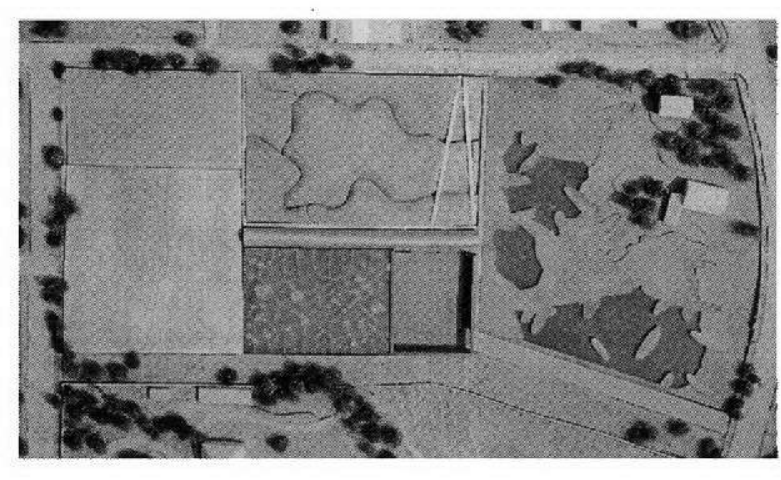

Figure 4 Whitney Water Works, conceptual model.

\section{THE OKAVANGO DELTA SPA, 1997-}

Commissioned by developers Unchartered Africa, the Okavango Delta Spa by architect Lindy Roy is designed to allow visitors a chance to be consumed by nature. This unbuilt project is designed to be ecologically sustainable. The spa is located in the African Delta. It consists of seven guest houses or pods built on stilts above papyrus reed beds, a health spa and a dining pavilion. Each suite includes a buoyant fiberglass spa that floats on the surface of the water and a space for meditation. The pods are connected by floating walkways. A motorized wire-mesh lap pool will allow guests to swim safely 
alongside the natural inhabitants. Concepts that influenced the design include rhythms of African music and patterns of weaving common to the local culture. Throughout the project, space is organized according to experiences of tension and relaxation analogous to those found in the wild. The delta allows Roy's project to clearly demonstrate that nature is a crucial ingredient in the creation of a sensual environment. In both Holl's Cranbrook design and the Okavango Delta Spa, circulation and movement between the spaces are important. In plan, the forms of the walkways embrace the islands (sections of the spa) and the environment beyond the spa. My project applies this concept in an urban setting.

Walkways are used to connect the spa with the Riverwalk and the park across the water. Nature is drawn into my project as gardens and water elements surrounding spaces for meditation and relaxation. ${ }^{[9]}$

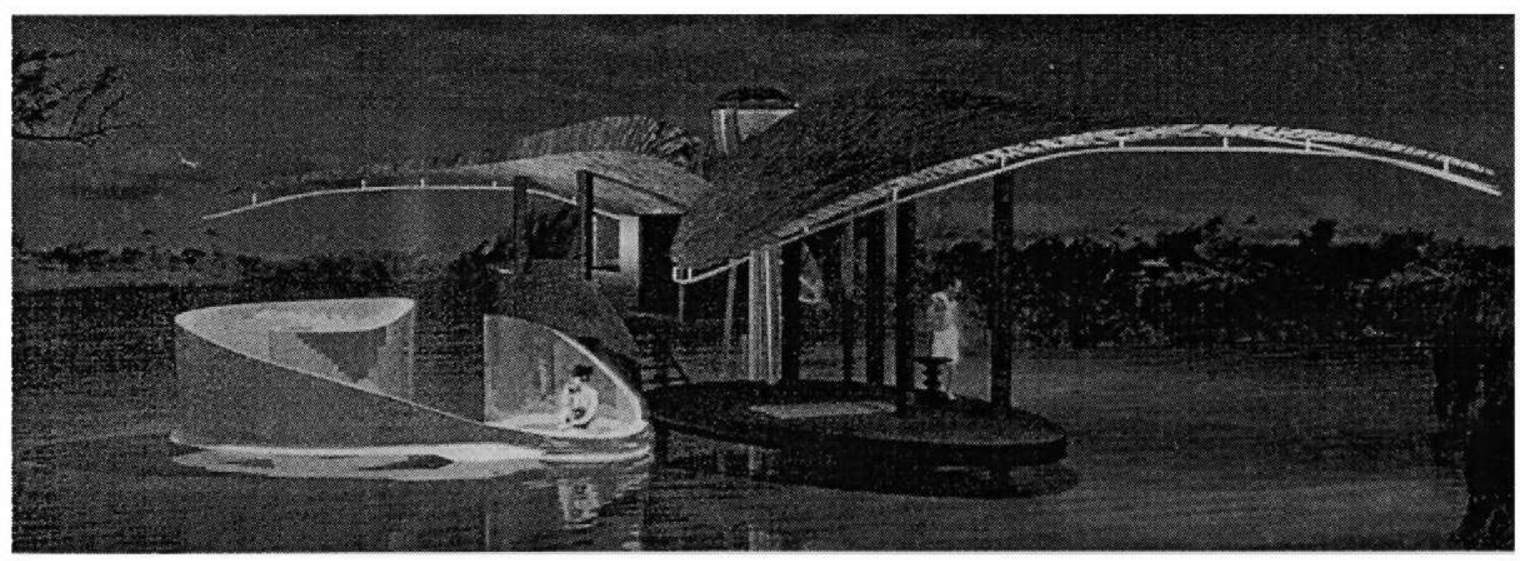

Figure 6 Okavango Delta Spa, guest pod with spa and meditation space.

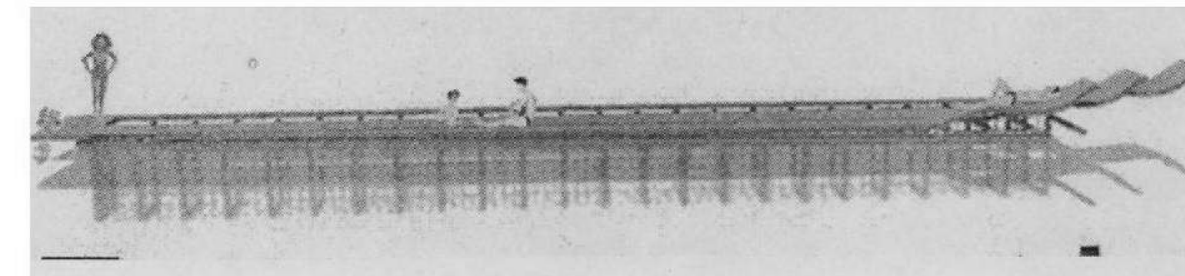

Figure 7 Okavango Delta Spa, motorized lap pool.
POOLHOUSE, 2000-

The Poolhouse by architect Lindy Roy uses water to relate to nature visually. Another unbuilt project, the house was designed for a wooded New York community, the Houses at Sagaponac. The community is a planned initiative by developer Harry Brown Jr. Over 30 architects were invited to design informal homes that are intimately related to nature. The project responds to its surrounding environment by blurring the distinction between the interior and the exterior spaces. The house surrounds the swimming pool so the sounds, colors and movement of water awaken various rooms of the house, each with a different character. The architecture is simple and fluid, and the flow of water is continuous. A three-story tall water wall covered by blue mosaic tiles is visible from a distance. A section of the wall is designed as a waterfall that neatly spills into the pool. The pool stretches from the courtyard through the interior of the house. All of the water elements are integrated with each other: the lap pool, steam room, wet bar and the bathrooms. I enjoy the poetry that this project creates as it integrates the water elements, blurs the lines between the interior and exterior, and the way it adds the sounds and movement of water within the design. My project utilizes these concepts as it narrates the water cycle, and like the Poolhouse, the flow of water is continuous. ${ }^{[11]}$
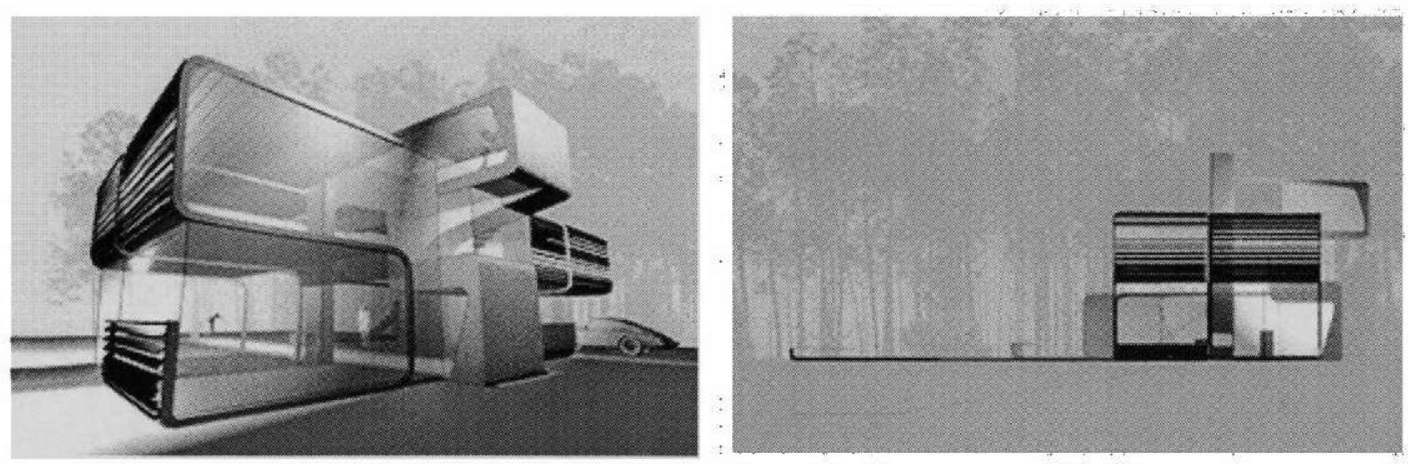

Figures 8 and 9 The Poolhouse, conceptual models. 


\section{VENETIAN POOL}

Decorator Phineas Paist and landscape architect Frank Button designed the Coral Gables Venetian Pool for George Merrick in 1923. The pool is considered one of the first water parks, a term that has been redefined many times since. The pool was part of Merrick's vision of a Mediterranean style city filled with plazas, esplanades and fountains. It soon became the center of attraction for the city. In addition to its Spanish style detailing, vine covered loggias and shady porticos; the pool is a free-form lagoon with coral rock caves, a palm fringed island and water-falls. At one time, gondolas were a part of its charm. In summer, the pool is drained each night and refilled with the cool water from the aquifer.

This process has recently been integrated with new technology that allows the water to be recycled and naturally filtered back to the aquifer. Two pumps and two twelve-inch drainage pipes are used to draw the water up from the aquifer and return it to a cavern where it percolates through the ground and is returned. Over one hundred thousand visitors and residents enjoy a swim in the invigorating water each year. My project adopts the technology used by the Venetian Pool. The water for the spa is drawn from the aquifer and it is continually renewed and recycled. This will allow most of the water to remain untreated and form a stronger physical connection between the project and nature. ${ }^{[12][13]}$

\section{SITE ANALYSIS}

\section{URBAN SCALE}

The site is located along the New River in downtown Fort Lauderdale (Figure 10). Hyde Park Market and the Historic Stranahan House are the current habitants of the site. The market has closed and the site has deteriorated into vacancy. An analysis of the area and districts (Figure 11) associated with the site, reveals a need for a public space that can act as a town square, providing an entrance to the Riverwalk that meanders along the rivers edge. My thesis is designed to stimulate Las Olas Boulevard

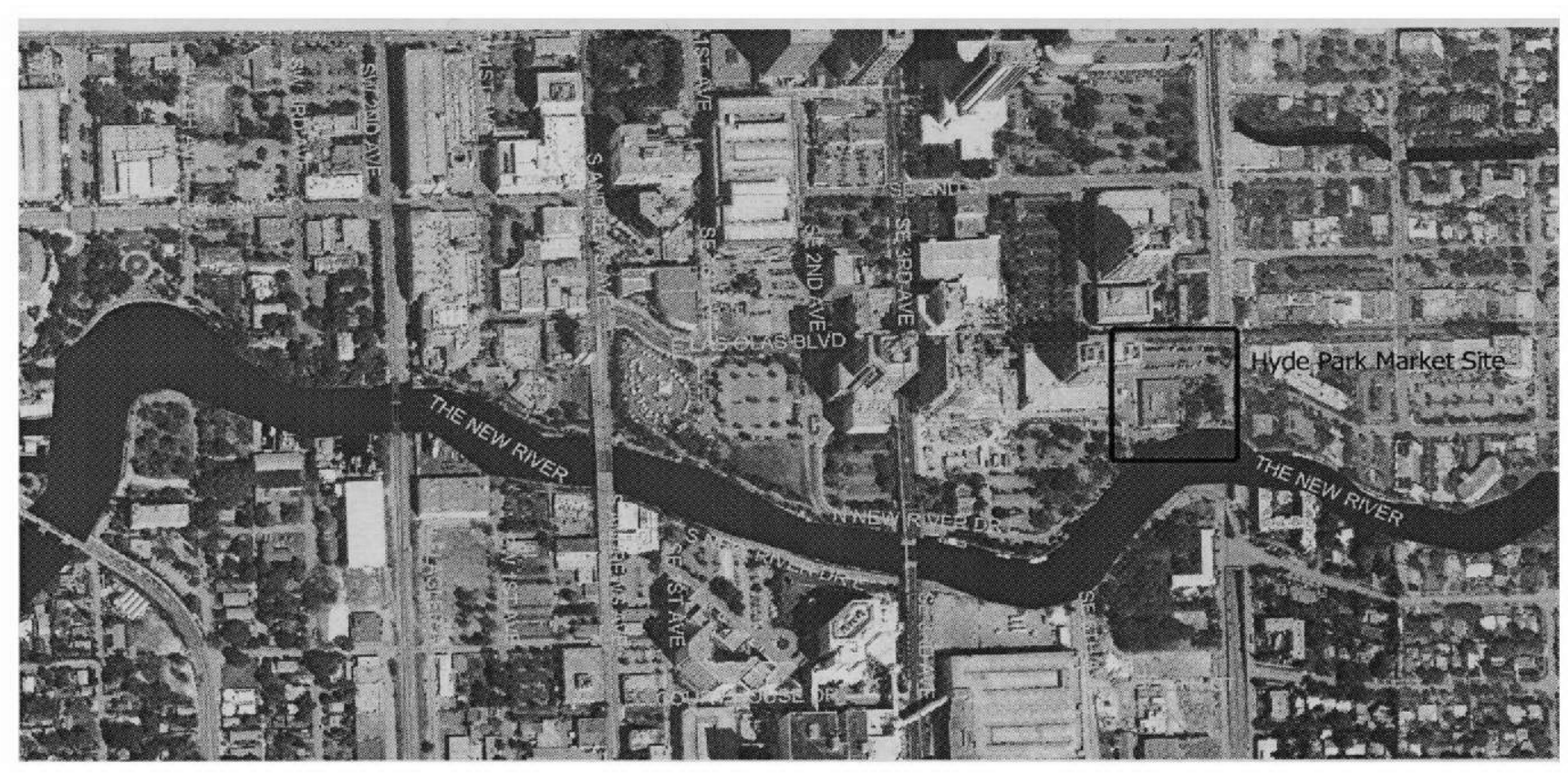

Figure 10 Downtown Fort Lauderdale, Hyde Park Market Site. N 亿 


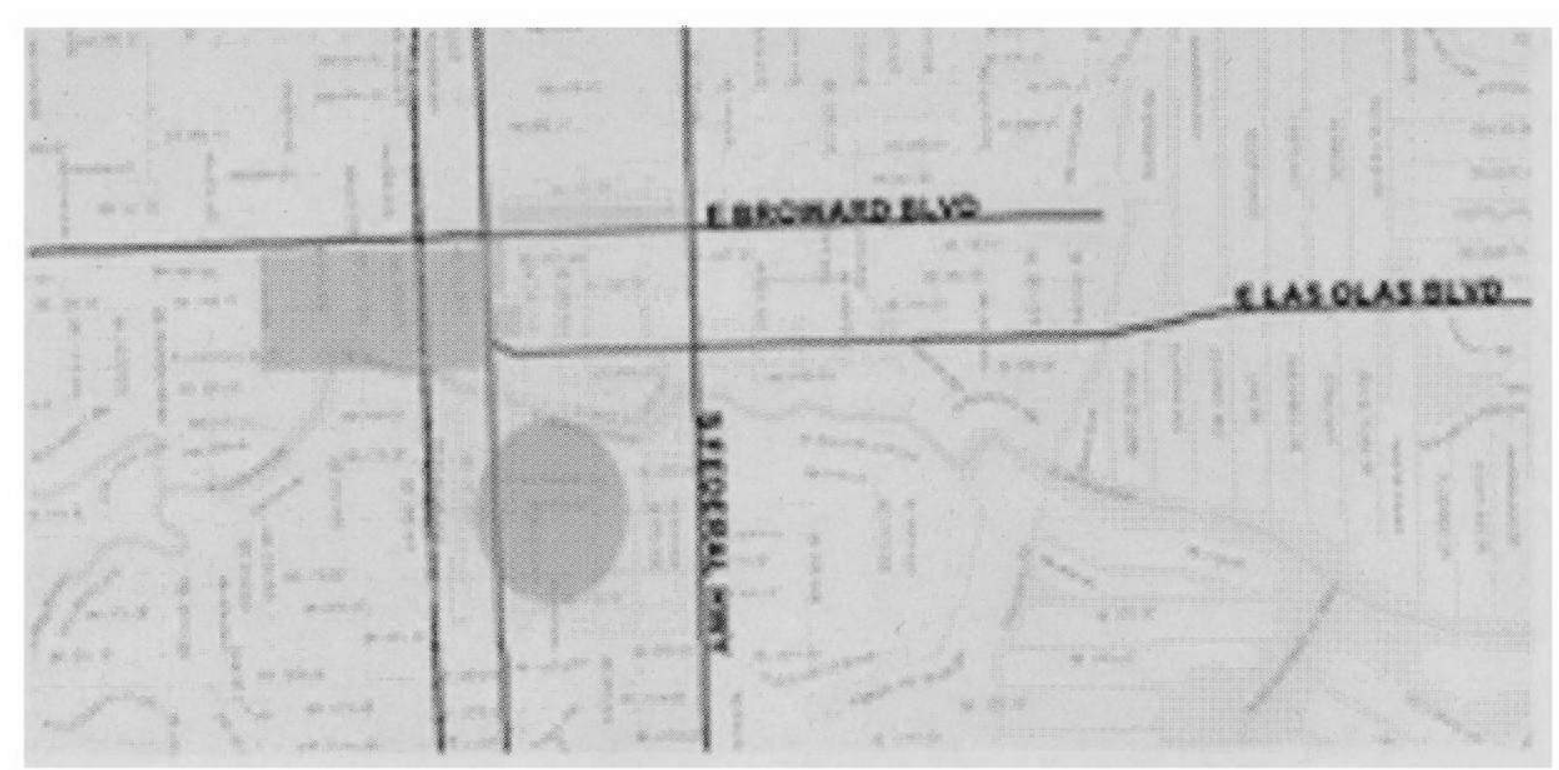

Cudding Use and Distriets. Downtown fon havderdate

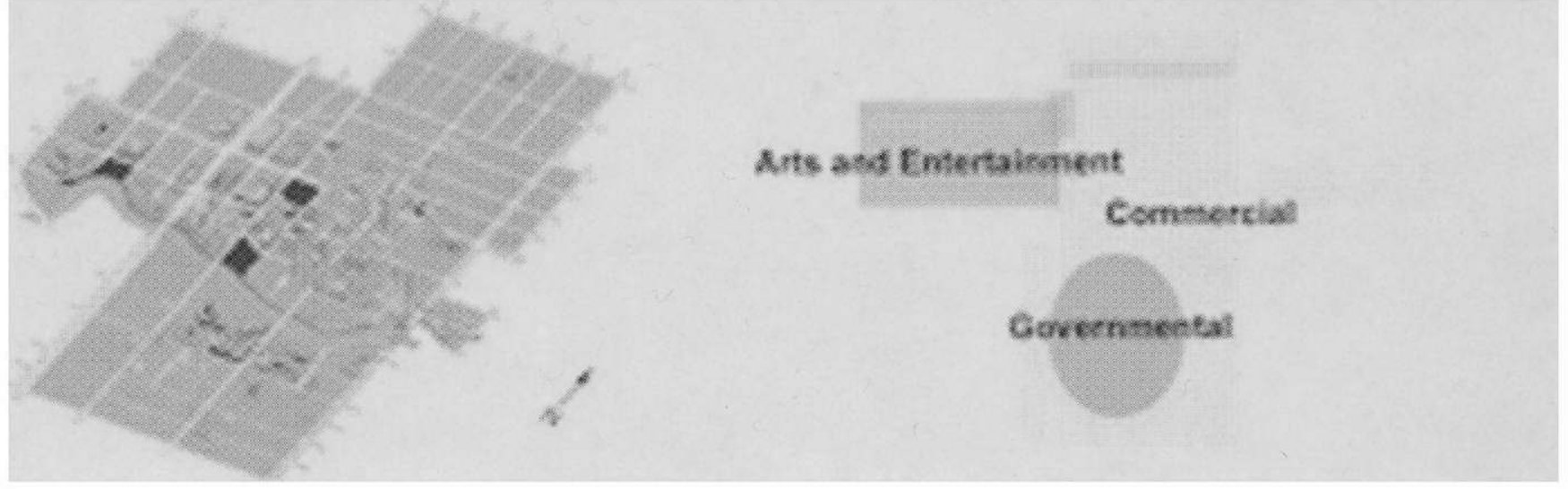

Figure 11 Downtown Fort Lauderdale, Districts and Building Use Diagram.

Las Olas Corridor I Riverwalk: Pedestrian Use Cycles
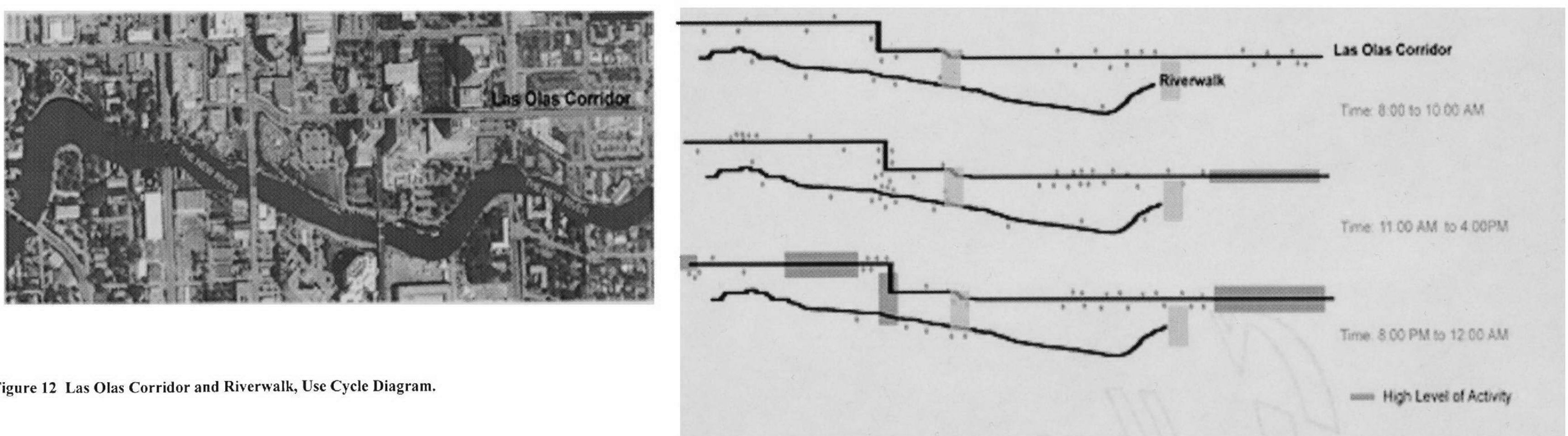

Figure 12 Las Olas Corridor and Riverwalk, Use Cycle Diagram. 


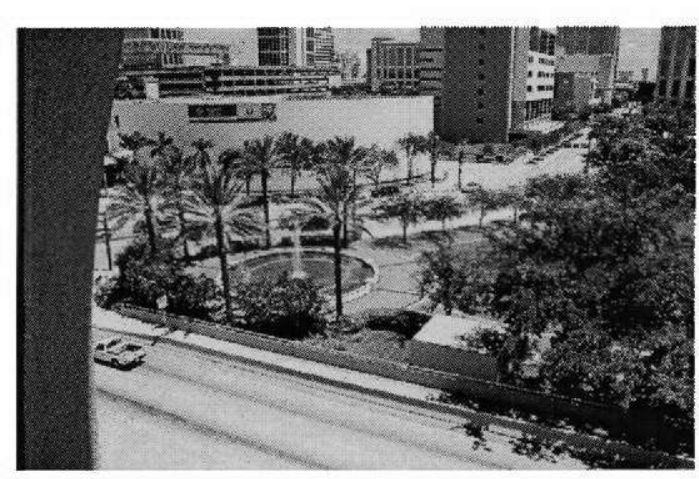

Figure 17 Huizenga Plaza and Museum. Transition between Arts and Entertainment and Business Districts.

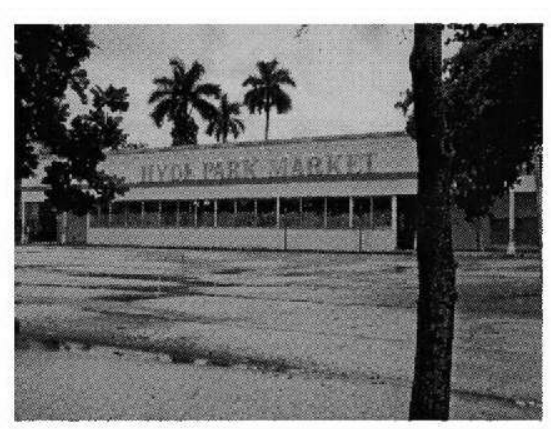

Figure 19 Hyde Park Market, photographed from Las Olas Boulelvard.

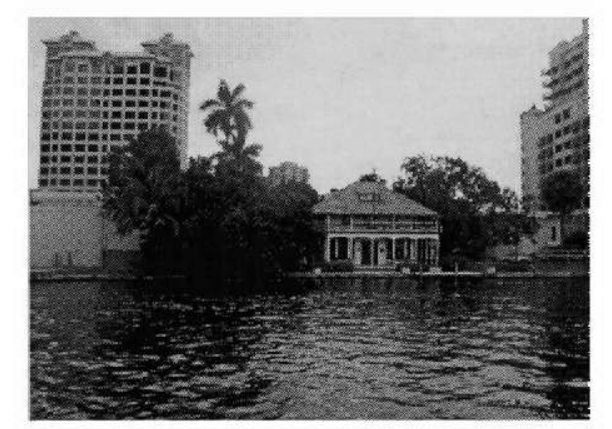

Figure 20 Hyde Park Market, Stranahan House, photographed from south side of river
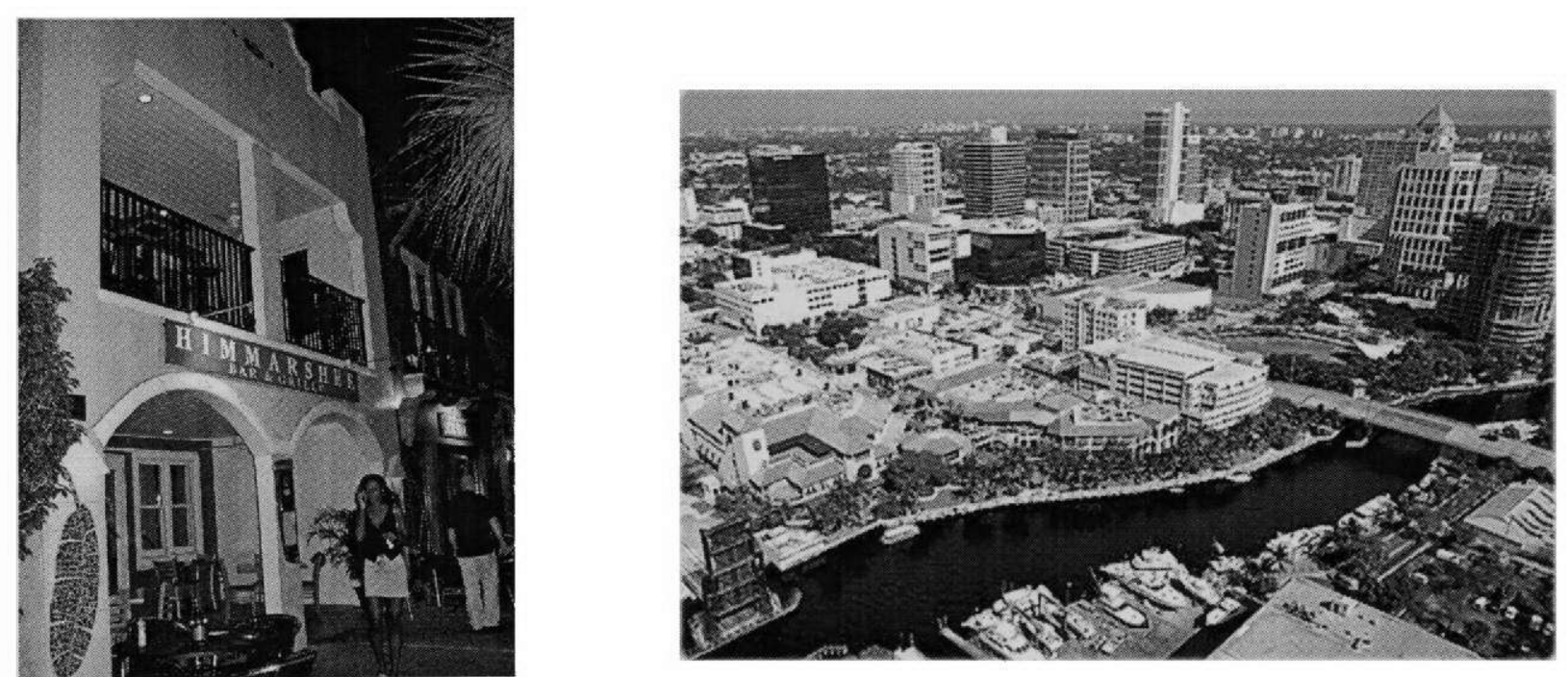

Figure 15 Downtown Himmarshee
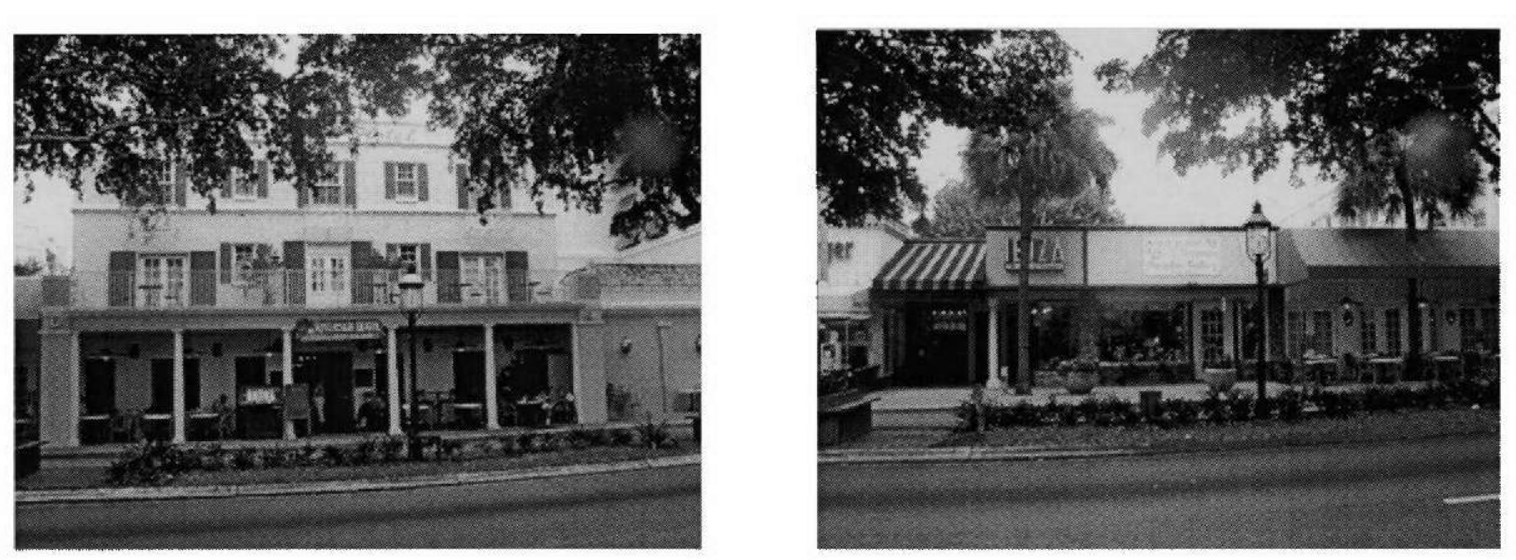

Figures 21 and 22 Las Olas Shopping District, Las Olas Blvd. east of Hyde Park Market.
Figure 16 Riverfront, Arts and Entertainment District. Photograph, looking east towards Business District. 


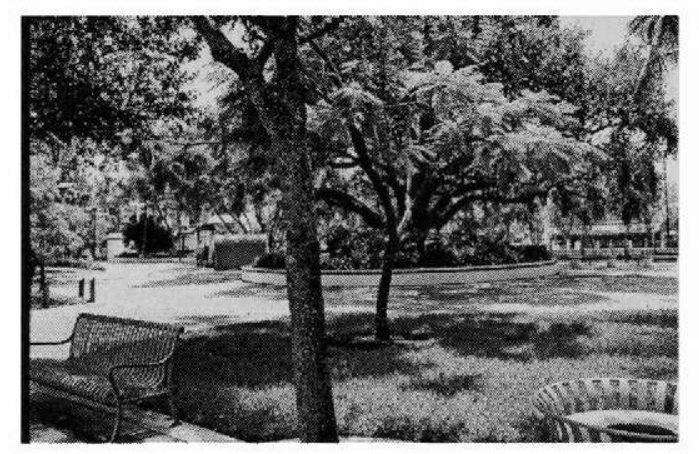

Figure 23 Riverwalk, behind Huizena Plaza.

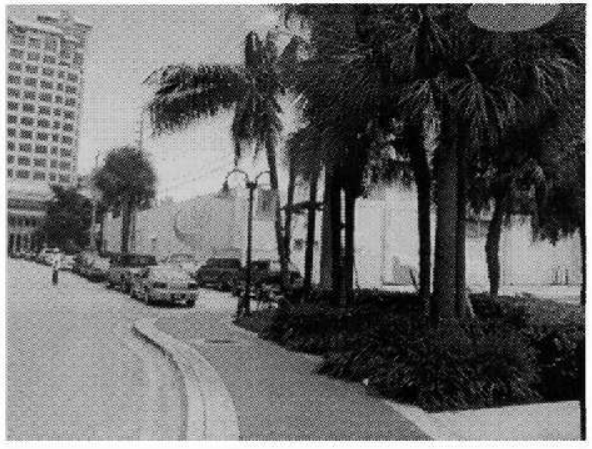

Figure 24 End of Riverwalk, behind Hyde Park Market.

\section{HYDE PARK MARKET SITE}

The Downtown Development Authority of Fort Lauderdale (DDA) has analyzed the downtown area and has already started to implement a plan for its future growth. The first level of all buildings in the Business and Courts Districts is reserved for mixed-use development. Many current buildings have started renovating, and more mixed-use developments will be constructed along the south side of the river. Several residential high rises are being built throughout the area in an effort to revitalize

downtown. The DDA proposal includes extending the Riverwalk along the North side of the river and a two-block area along the south side of the river. The Riverwalk, along with parks and open green space, can be treated as a loop, and if completed, can be an effective way to bring pedestrians to the riverfront connecting the adjacent neighborhoods and districts. The existing and proposed open space diagrams (Figures 25 and 26) below demonstrate this link.

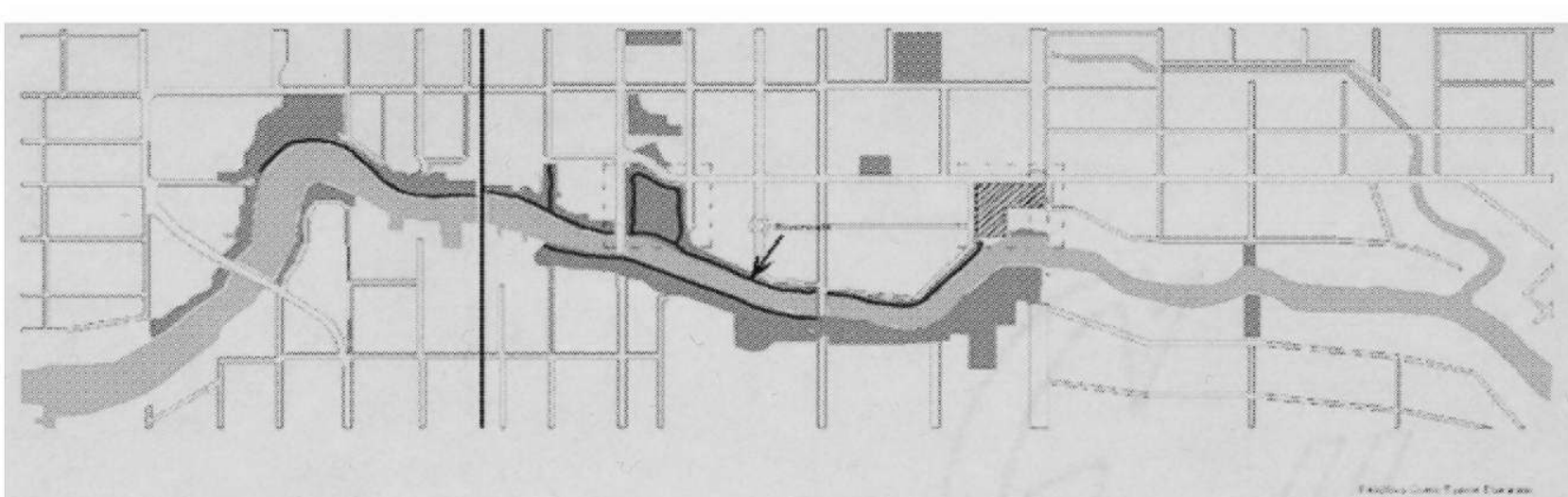

Figure 25 Existing Open Space Diagram. The dark green line represents existing Riverwalk.

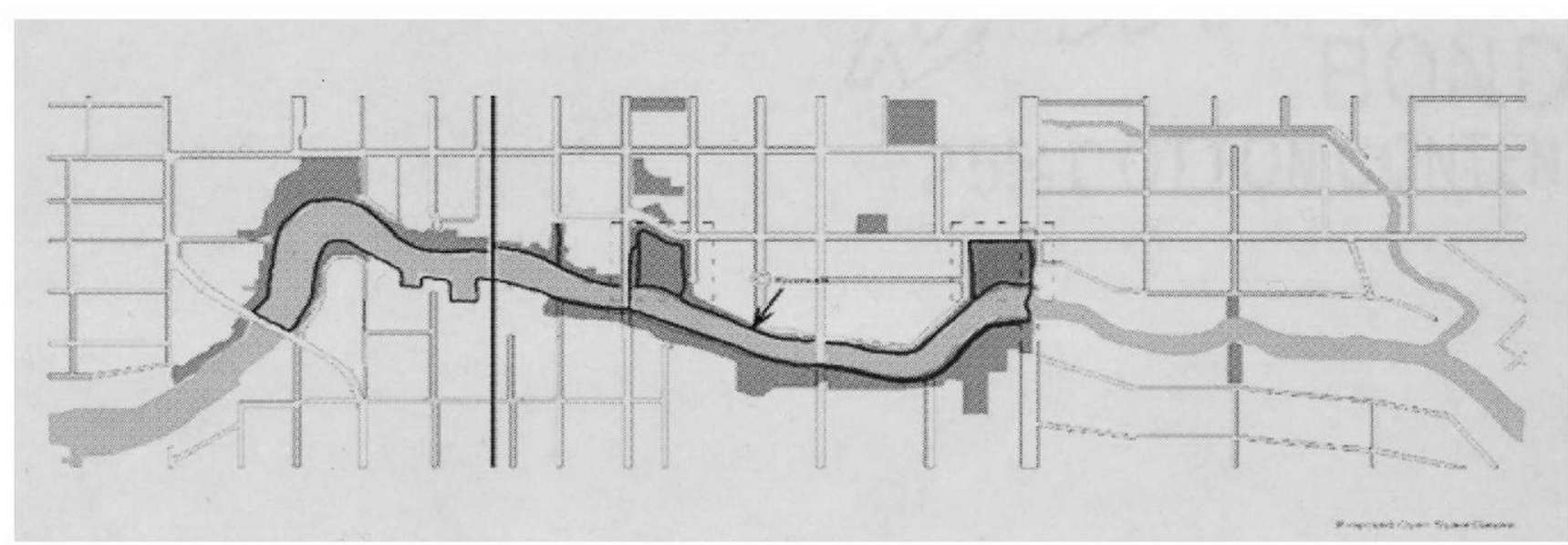

Figure 26 Proposed Open Space Diagram. The dark green line represents the Riverwalk.

\section{DESCRIPTION OF PROGRAM}

At ground level my project transforms the Hyde Park Market site into a public square and pool that acts as a reception area for the different districts associated with downtown: Arts and Entertainment, Business, Historic and the Las Olas Shopping. It will be shared by the residents, those working in the area, and by the people that are using the Riverwalk. The upper levels are an urban spa designed to 
generate a more private experience that presents water for reflection and relaxation. It will be open to the public and, like the square, it will be used by the people living and working in the downtown area.

The square will include interactive informative kiosks, a café and an outdoor seating area to

activate the perimeter of the square. The Riverwalk will extend, surround the site and the historic house adjacent to the square, and adjoin with a walkway following along side the public pool. It will serves as a casual gallery to exhibit work by local artists. A pedestrian walkway that involves the use of the

existing pump stations and the New River Tunnel will connect Hyde Park with a recreational linear park across the river. 


\section{ADDITIONAL SITE ANALYSIS, DOWNTOWN FORT LAUDERDALE}

DOWNTOWN FORT LAUDERDALE, CITY CORE

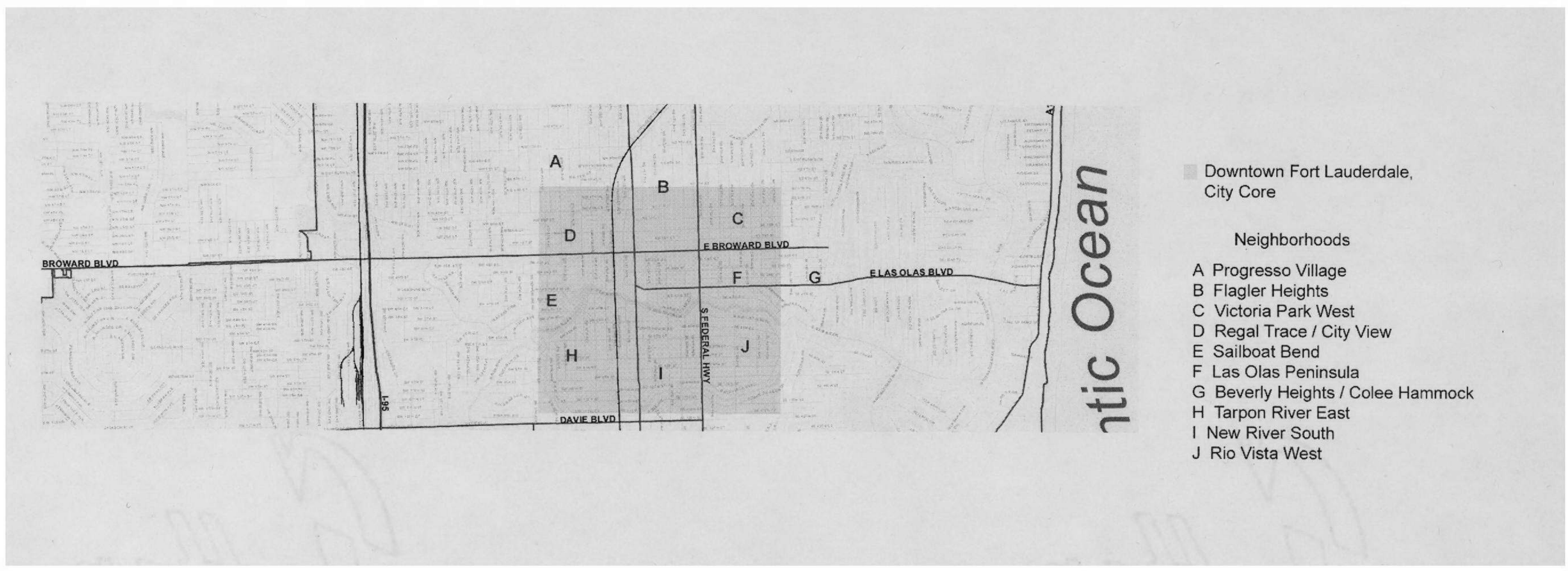

Figure 27 The site is located in Downtown Fort Lauderdale, Florida. The diagram illustrates the areas that break

down the downtown core. 
Points of Interest, Downtown Fort Lauderdale

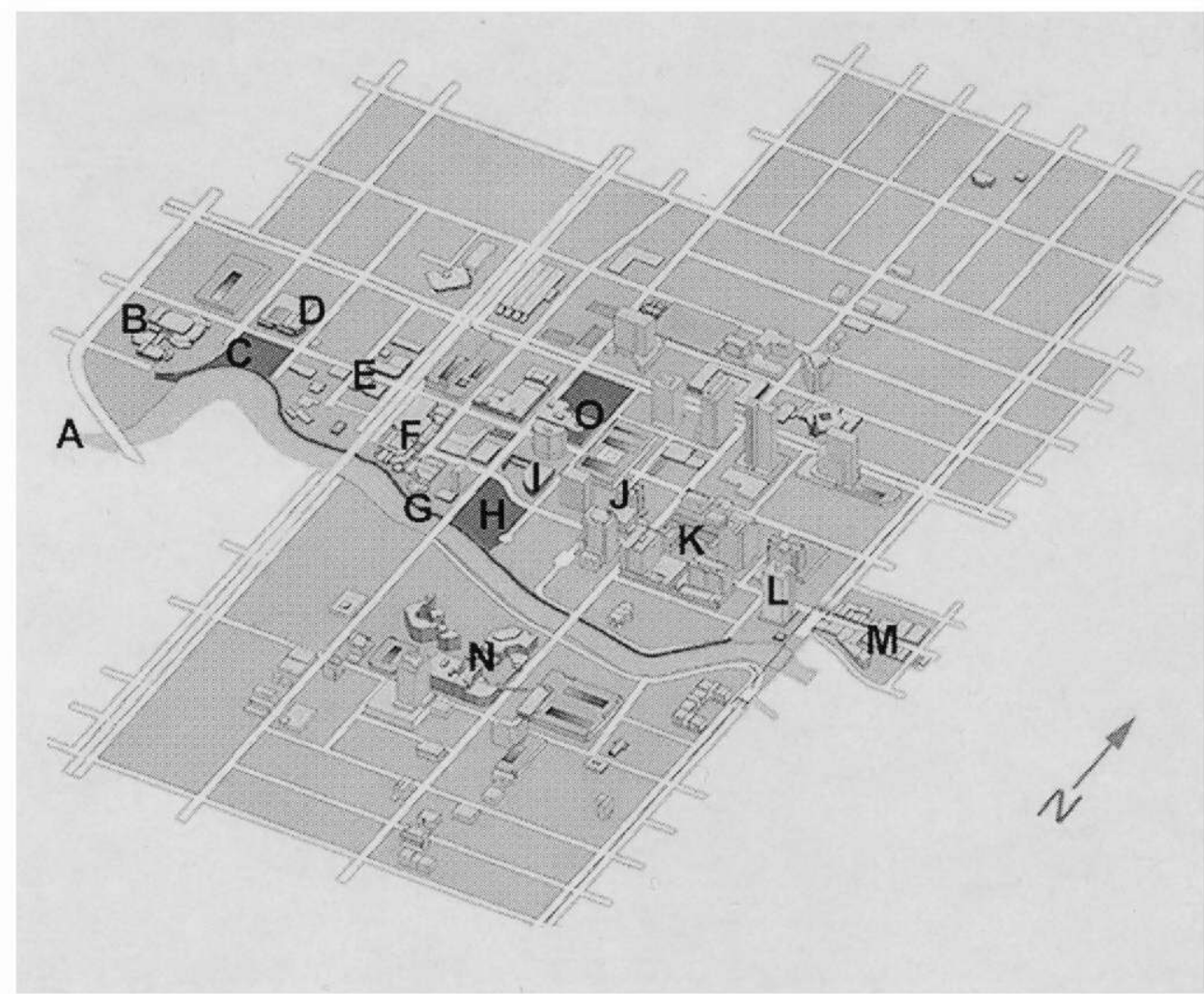

A New River

B Broward Center fot the Performing Arts

C Nature Preserve and Walk

D Childrens' Museum and IMAX

E Downtown Himarshee

$F$ Las Olas Riverfront

$G$ Riverwalk

H Site, DDA Plaza

I MOA

J FAU / BCC Complex

K Business District

L Las Olas River House

M Las Olas Shopping District

N Courts Distric

O Main Library

H

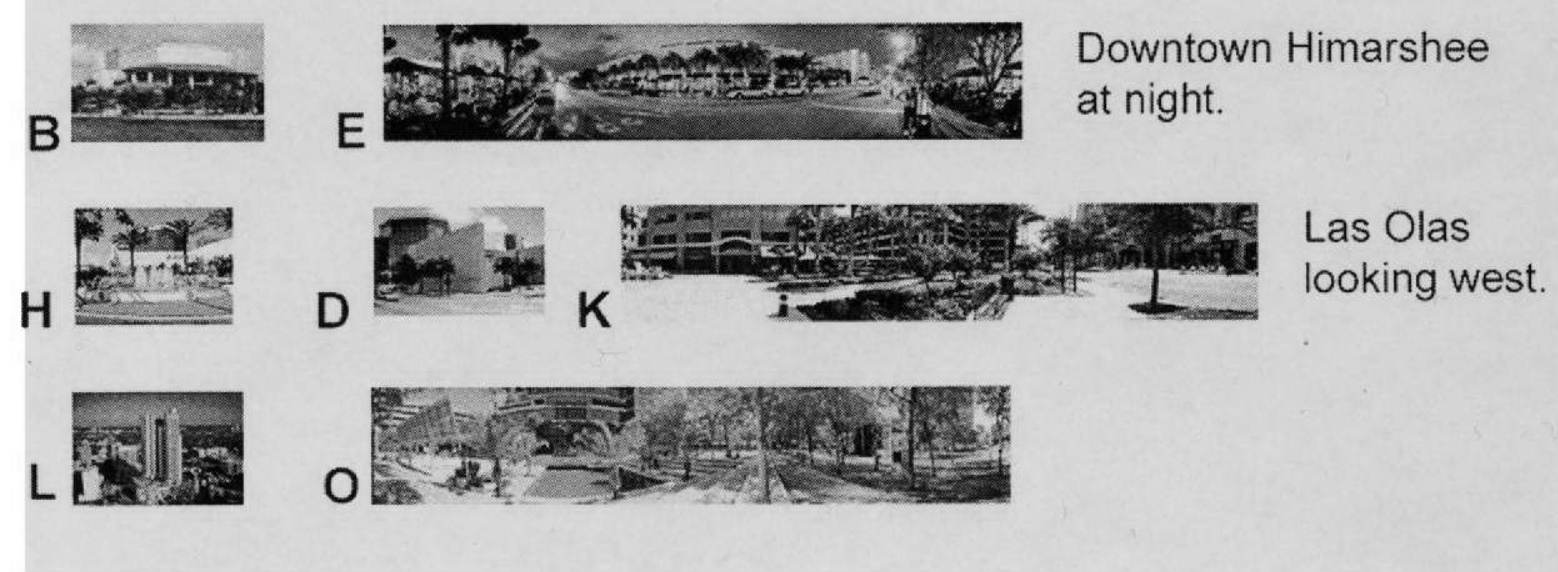

$\mathrm{H}$

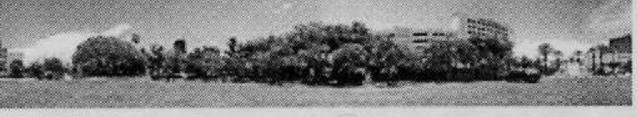




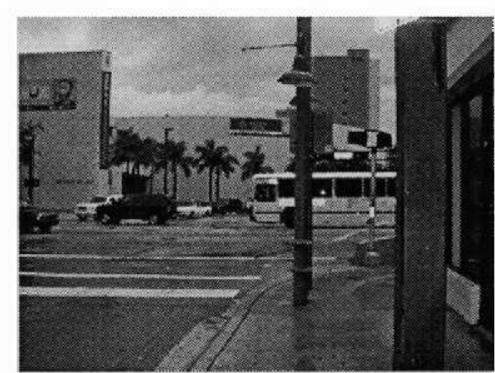

Andrews and Las Olas Intersection

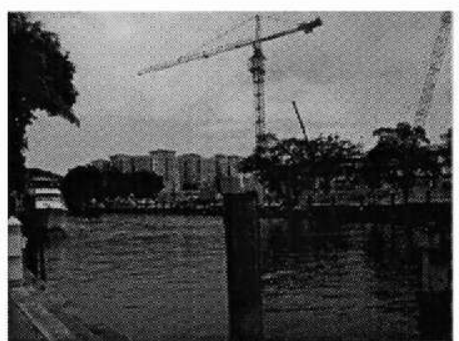

New Residential

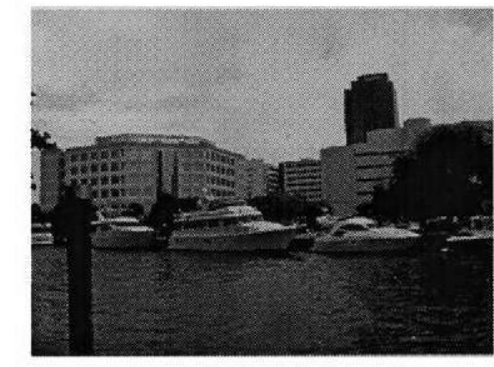

Court Buildings

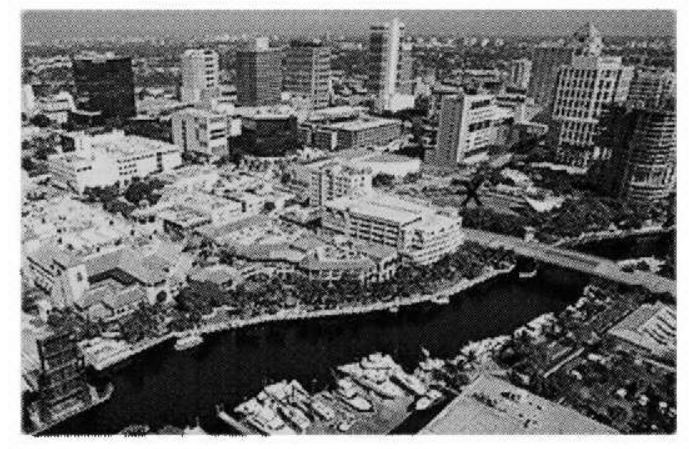

Problems:

The intersection at Andrews and Las Olas is large and not pedestrian friendly.

Las Olas is disconnected between the Business District and Las Olas Riverfront. The FAU/BCC Complex is introverted. More services need to be added at street level to connect east and west Las Olas. Services should also be added to activate the Himarshee area west of Riverfront at more times.

The south side of the river is underdeveloped at the rivers edge.

There are no pedestrian specific paths to cross the river.

New Residential

Figure 29 The site analysis analyzes some weaknesses that contribute to the decline of the Hyde Park Market site.

The developing residential high-rises are a temporary problem caused by construction. After they are finished, the area will strongly benefit from their presence. 

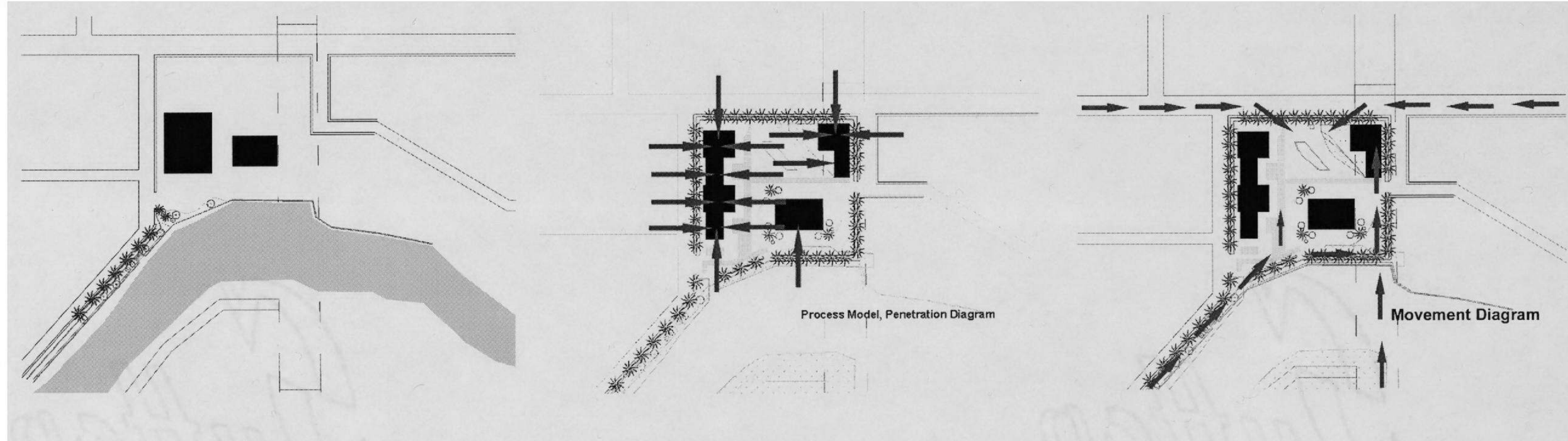

Figure 30 Analytical Diagrams: existing site, penetration and proposed movement. 


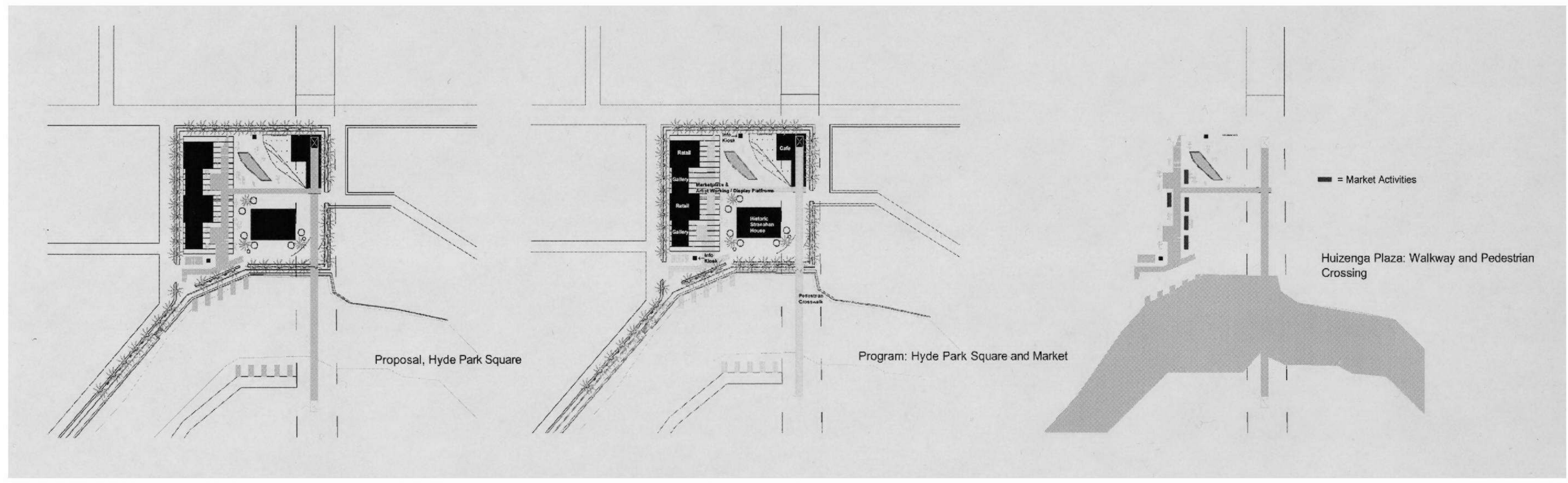

Figure 31 The Analytical Diagrams (Figures 30 and 31) illustrate some of the early concepts and investigations:

existing site, penetration diagram, proposed movement, Hyde Park Square, Hyde Park Square and Market, and

walkway with pedestrian crossing. 
VI. DESIGN DEVELOPMENT, CONCEPTUAL INSPIRATION AND PRECEDENTS

ARCHITECTURE AND WATER
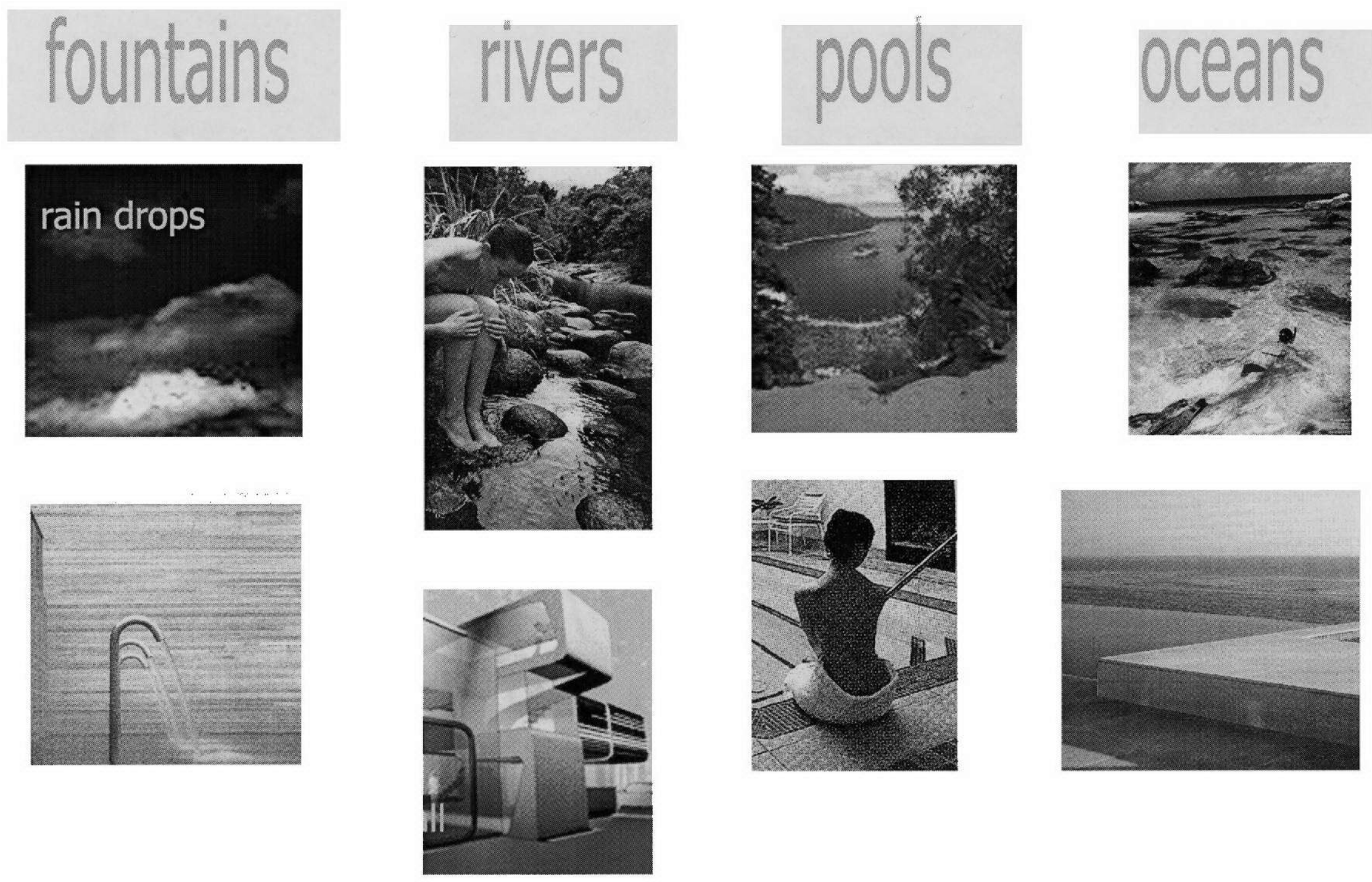

Figure 32 Architectural Presentation of Water. 
Site Inspiration
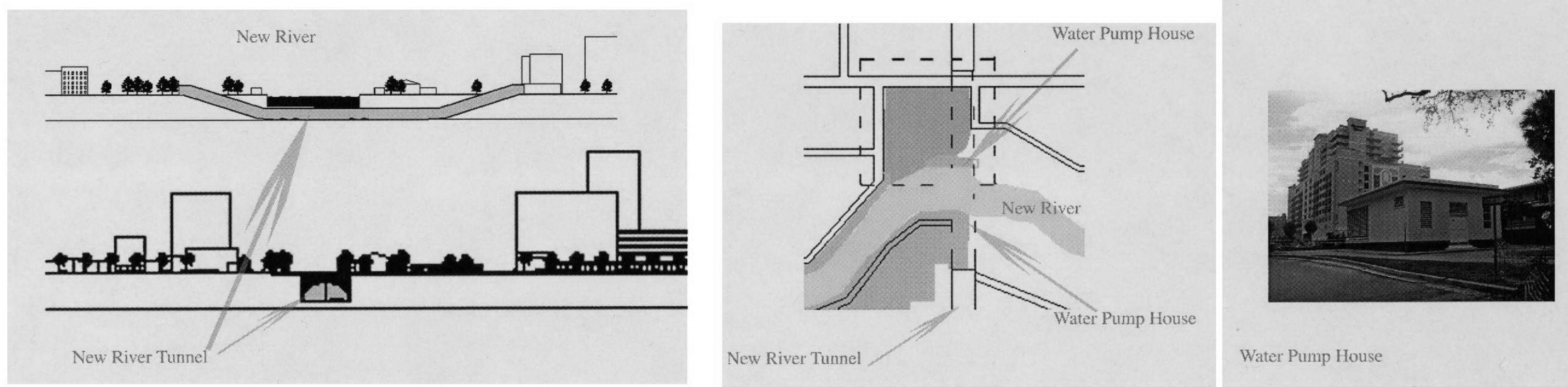

Water Pump House

Figure 33

South / North Section, East / West Section, site diagram, photograph of water pump house.

The diagrams depict the inspirational site elements that are related to water. The New River Tunnel runs directly

beneath the site and the river. The site rests directly on the New River. The pump stations are simple, but

five minutes after a rain, they come alive as the water rushes through them, from the city and into the river.

Most of the site is currently covered in paving. The design will allow all of the water that reaches the ground to be

collected or permeate back to the aquifer. 


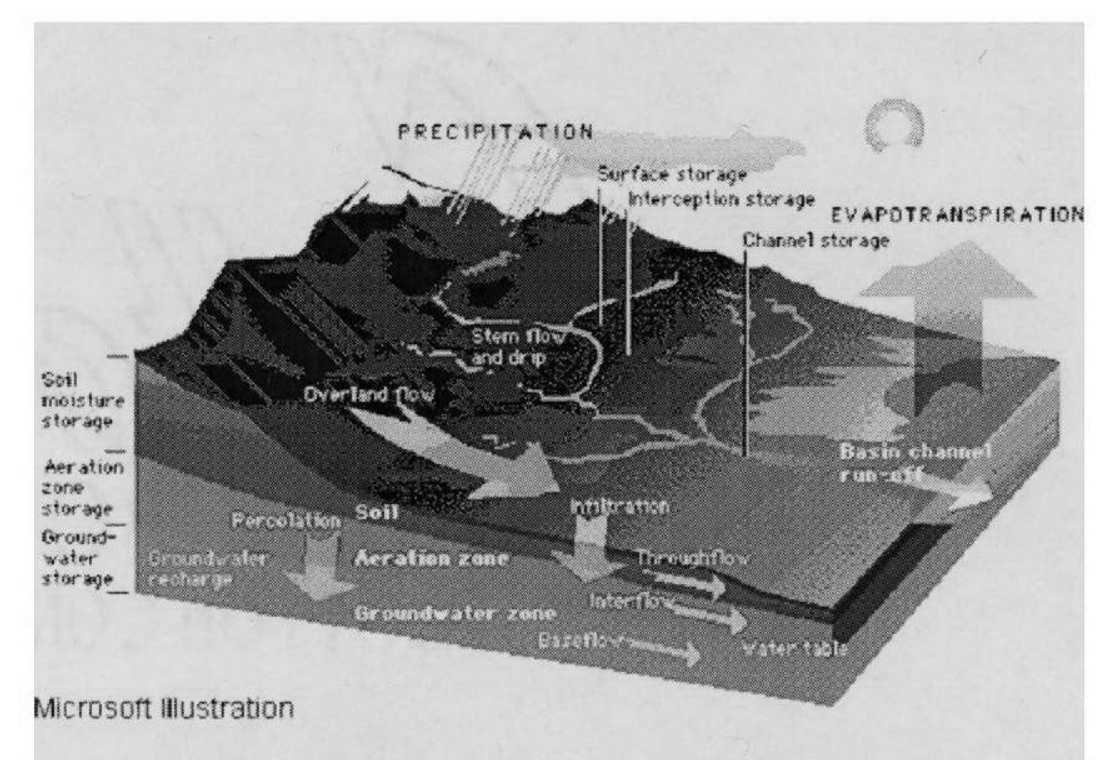

The Water Cycle

The water cycle consists of four stages: storage, evaporation, precipitation, and runoff. Water is stored in oceans and lakes, in river channels, and in the ground. Evaporation, including plant respiration, changes water into water vapor. Precipitation occurs when water vapor in the air condenses and falls to the ground as rain, snow, ice pellets, or hail. Runoff is the movement of water downhill, and includes water flowing in streams, on the ground, and in the ground.

Illustration of the natural water cycle and its four general stages. The system is formed in levels allowing water to move continually downhill. The cycle responds differently to each region depending on its topography. These levels are reflected in the design of my project.

Figure 34 The diagram illustrates the four stages of the natural water cycle. 
Water Cycle and Form

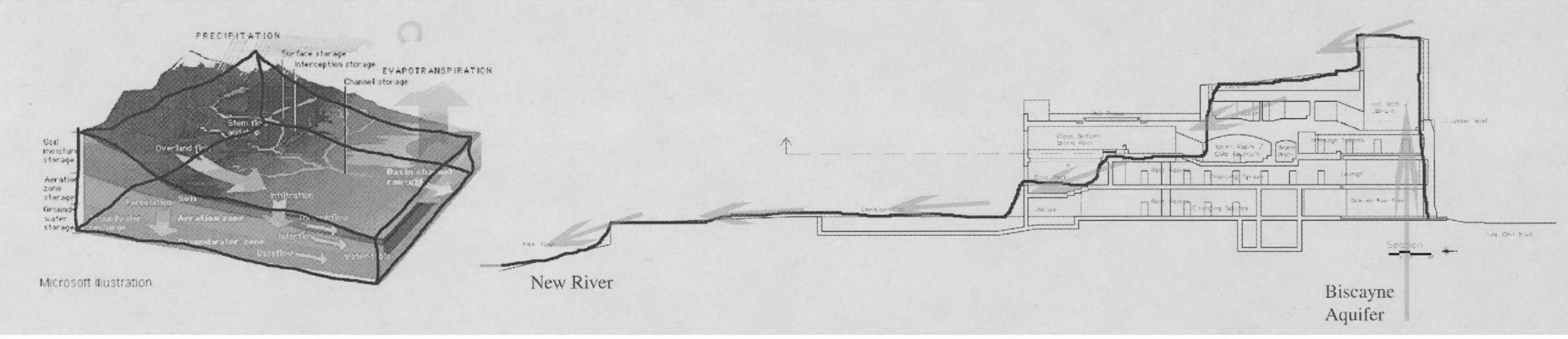

In nature, water flows downward until it arrives at the ocean. The Urban Spa emulates this phenomena as the building and the flow of water step downward until it is recycled or joins its conceptual equivalent of the ocean, the New River. 
The Baths at Caracalla in Rome
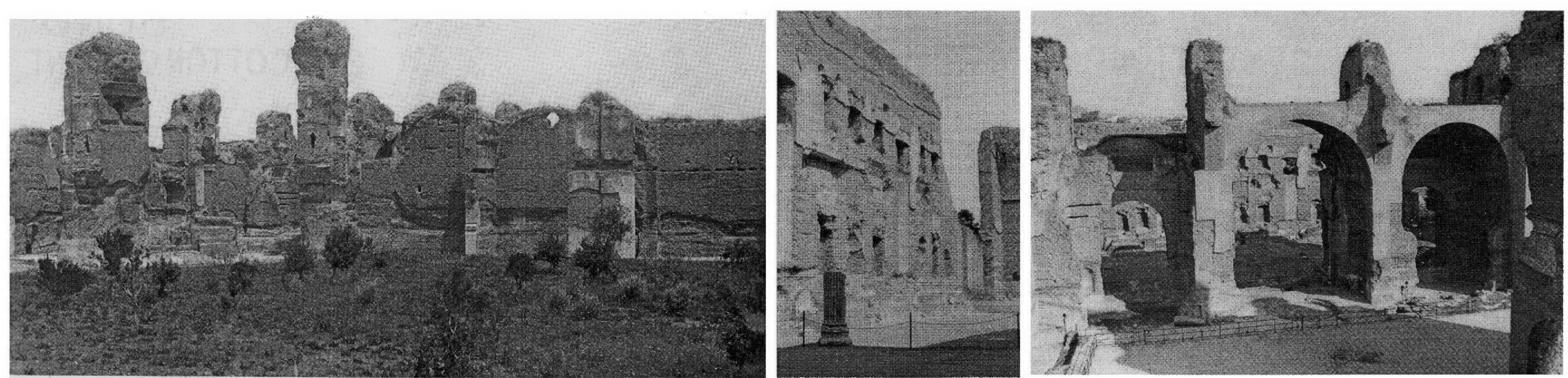

The photographs are of the ruins of the Baths of Caracalla in Rome: caldarium and hot rooms, the natatio ( $\mathrm{N}$ facade) and frigidarium ( $\mathrm{N}$ facade). 


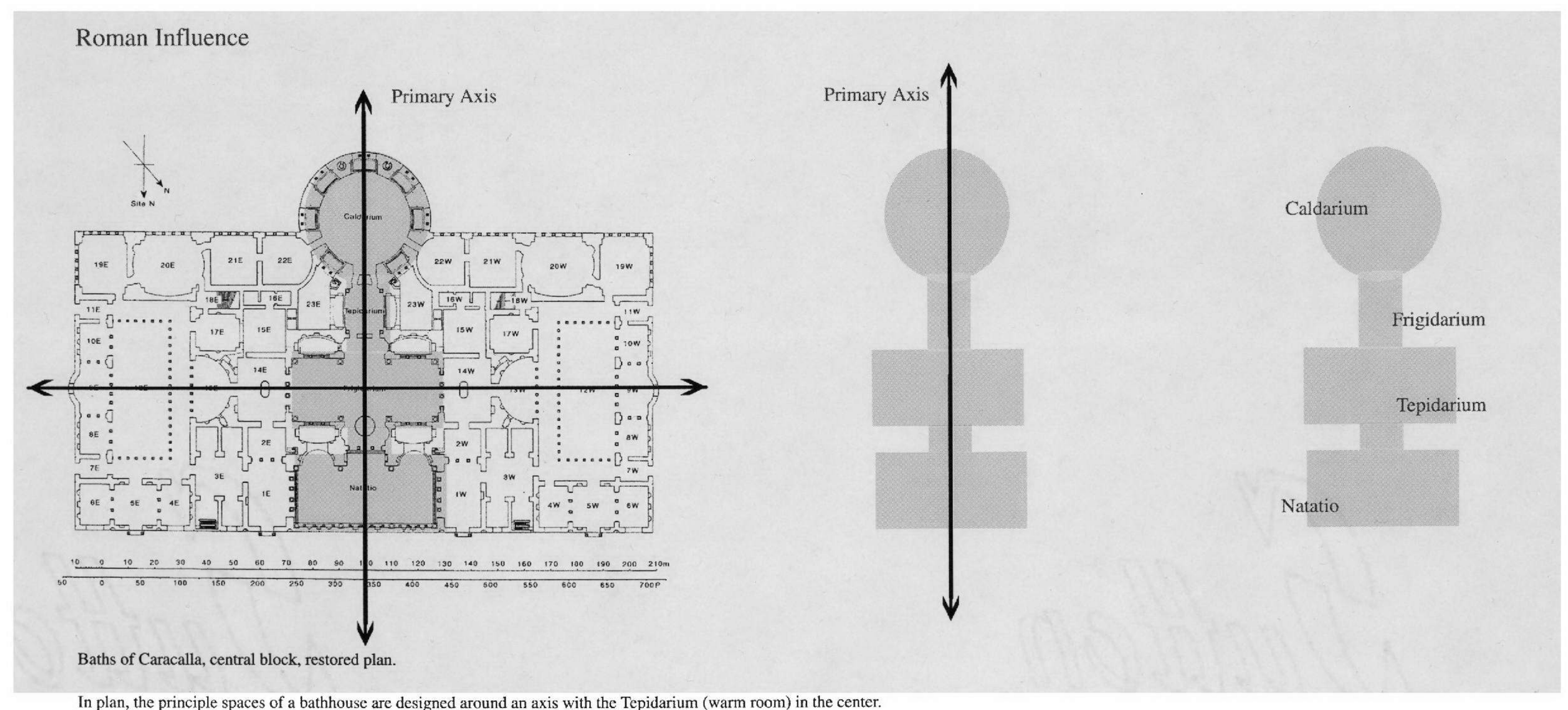

In plan, the principle spaces of a bathhouse are designed around an axis with the Tepidarium (warm room) in the center. 


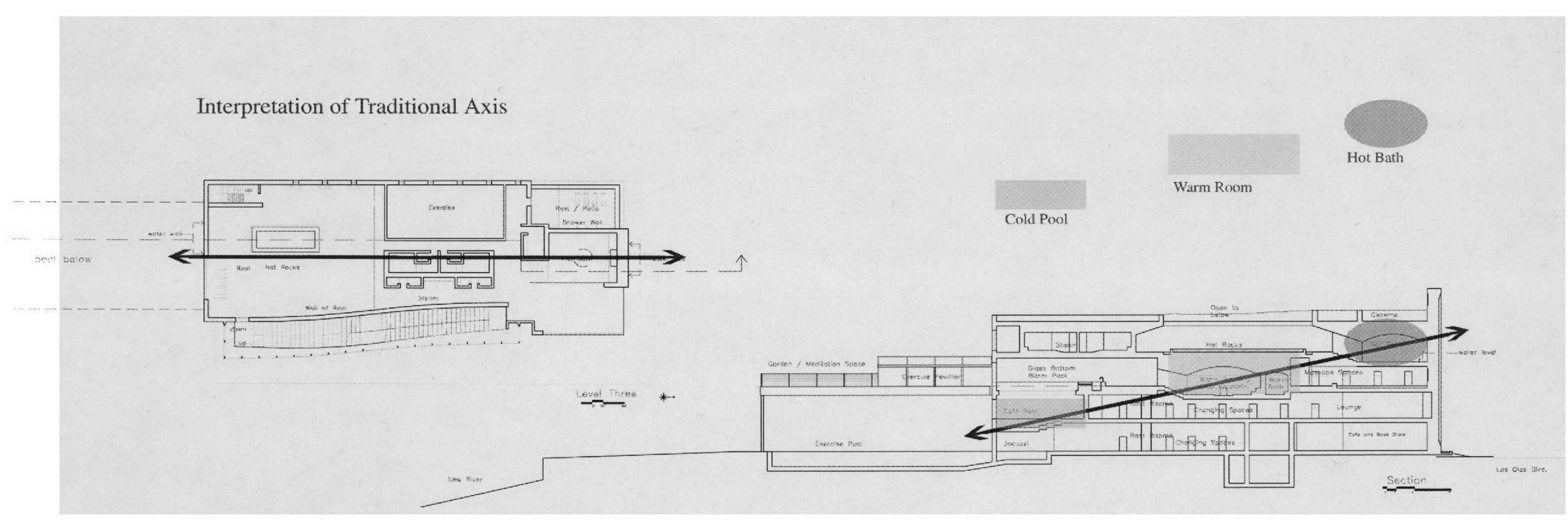

The Urban Spa, early plan and section diagrams.

The diagrams depict how the traditional axis of the Roman Bath carried through in the design of my project. In section, the axis exists diagonally with the Warm

Room situated in the heart of the spa. The temperature of water also begins to influence the design and divides both the plans and section into temperate levels. 
Fountains
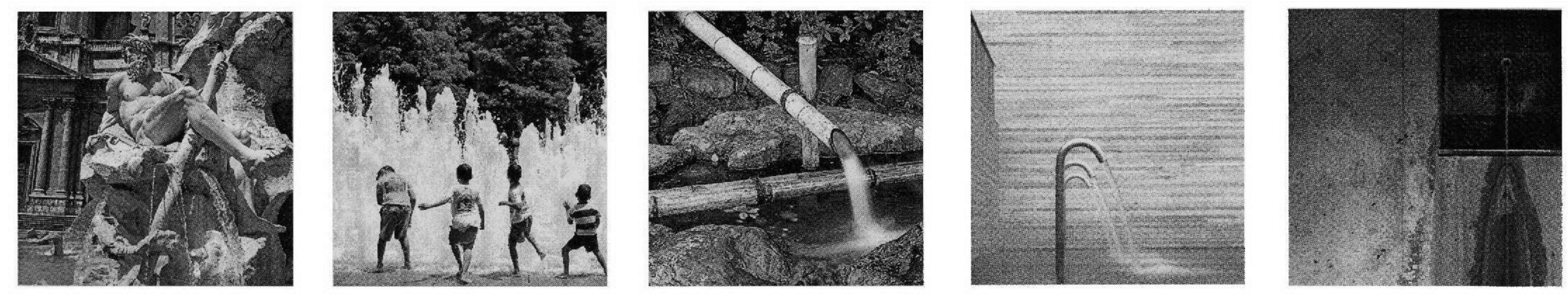

Fountain of the Four Rivers, Rome, Italy; Fountain Place, Dallas Texas; Byodo-in, Kyoto, Japan; Thermal Bath Vals and Thermal Bath Vals, Vals, Graubunden.

Fountains exist in many types and styles. The way that the water is controlled or allowed to move and flow within the fountain initiates different emotions. 
Fountain Forms by Bernard Forest de Belador
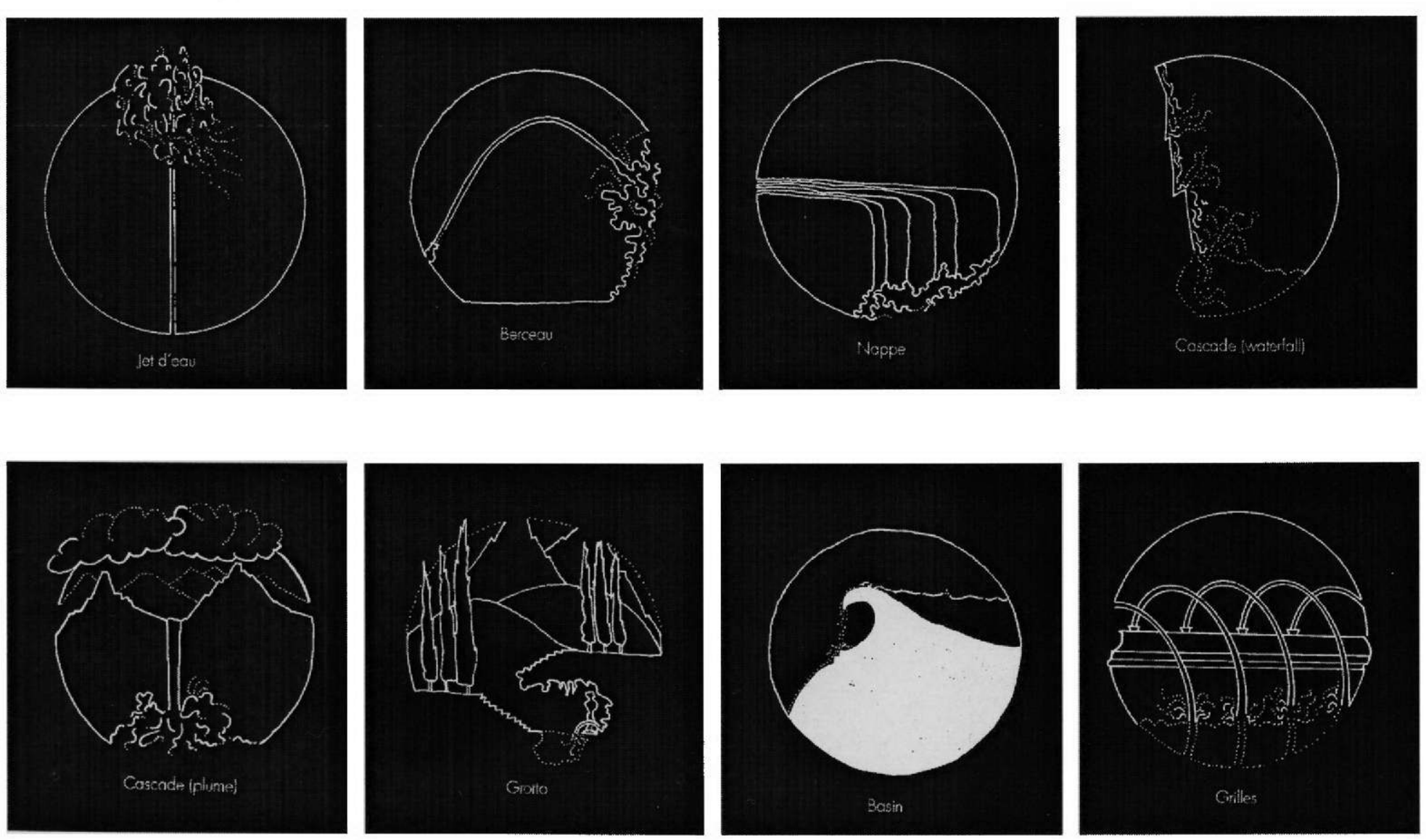

Fountain forms derived from nature remain standard shapes today. 
A Modern Spa
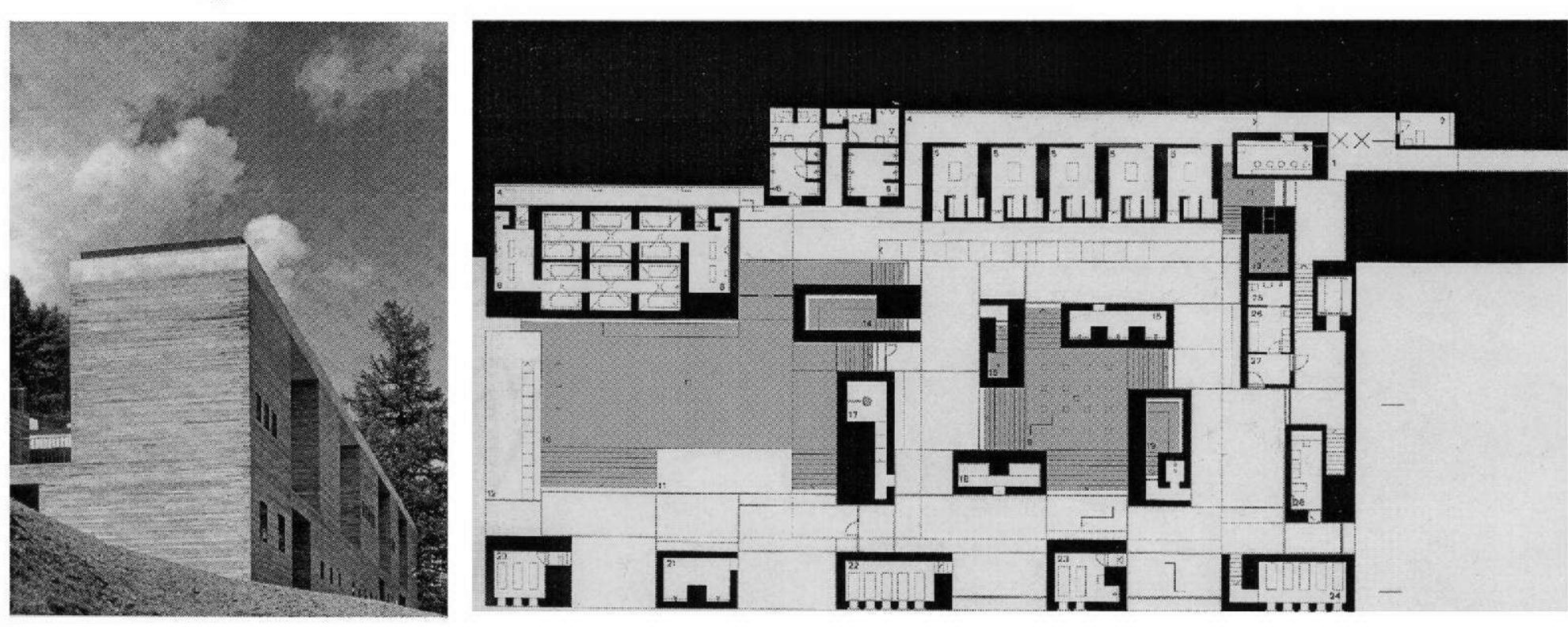

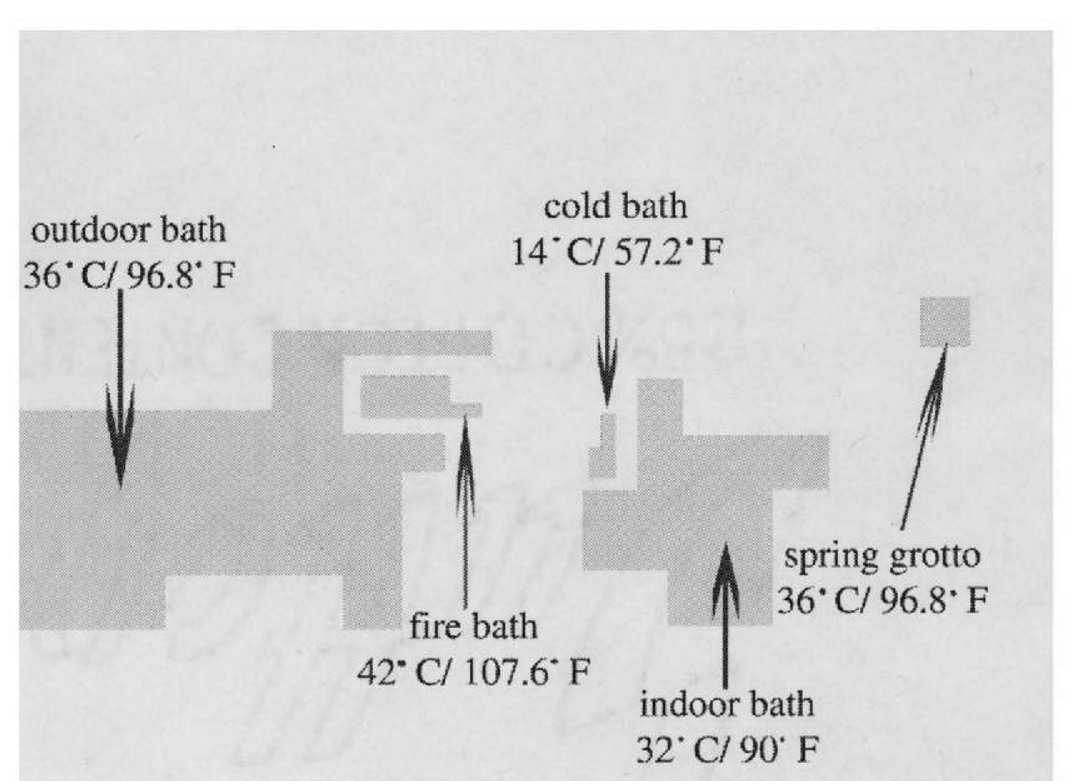

Thermal Bath Vals, Vals, Graubunden, 1990-1996. Exterior photograph, bath level plan and bath analysis'.

The Thermal Bath of Vals is a modern day spa designed by Peter Zumthor. The diagrams depict how the size and temperatures of the baths have been influenced by time. The size of the Tepidarium or warm spaces has increased. In this example the warm spaces are pools, but they can also be designed as saunas. Vals is exceptionally designed and has many influences on The Urban Spa including the sizes of the spaces and their layou

The spa is built on a spring. The water in the spring grotto is its natural temperature. In essence, this gesture highlights the importance of the water and celebrates where it came from. 


\section{SKETCHES}

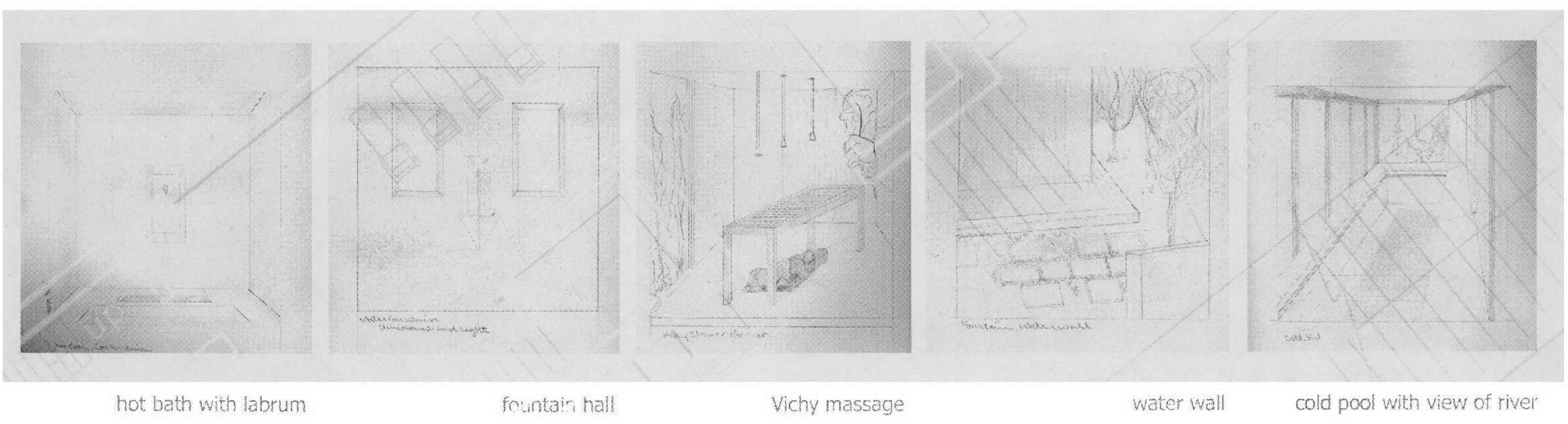

Figure 42 The sketches illustrate some of the initial concepts that influenced the design process. 


\section{DRAWINGS}

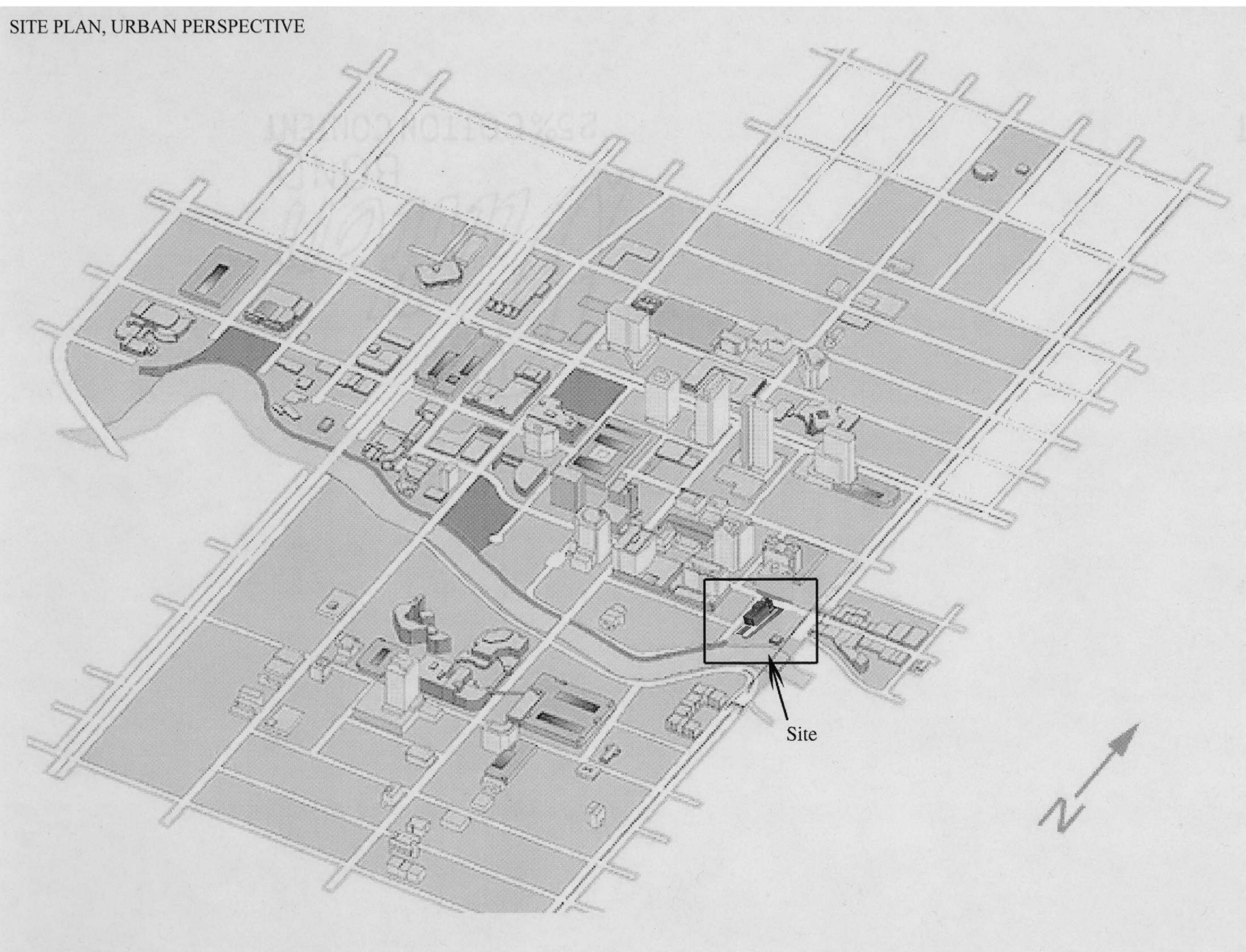

Figure 43 Urban Perspective, drawing of downtown Fort Lauderdale. 

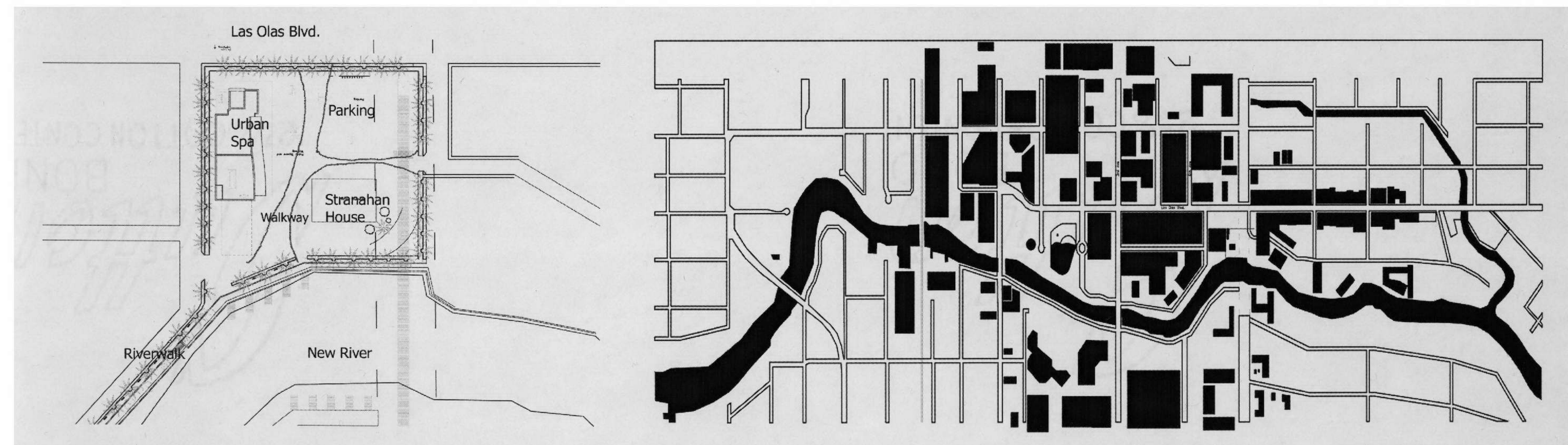

Figure 44 The site schematic diagram illustrates the approximate layout of the designs site. The figure ground

diagram depicts the density of the site and surrounding areas. 

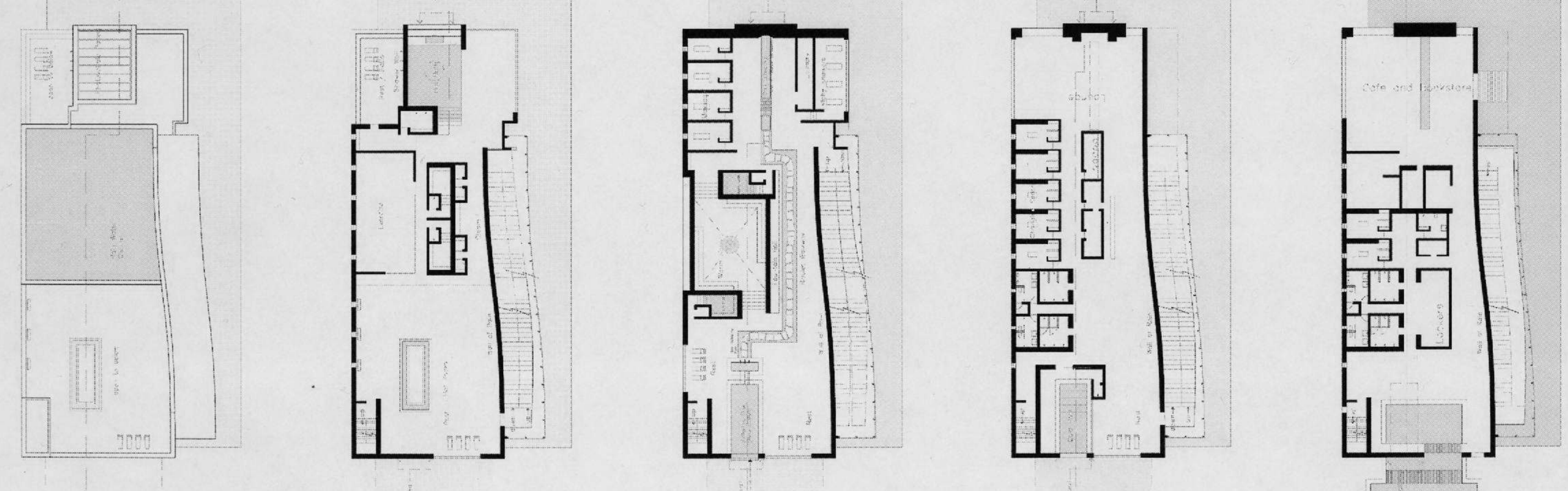

$\rightarrow+$

$-\rightarrow$

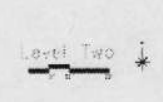

$-+$ 


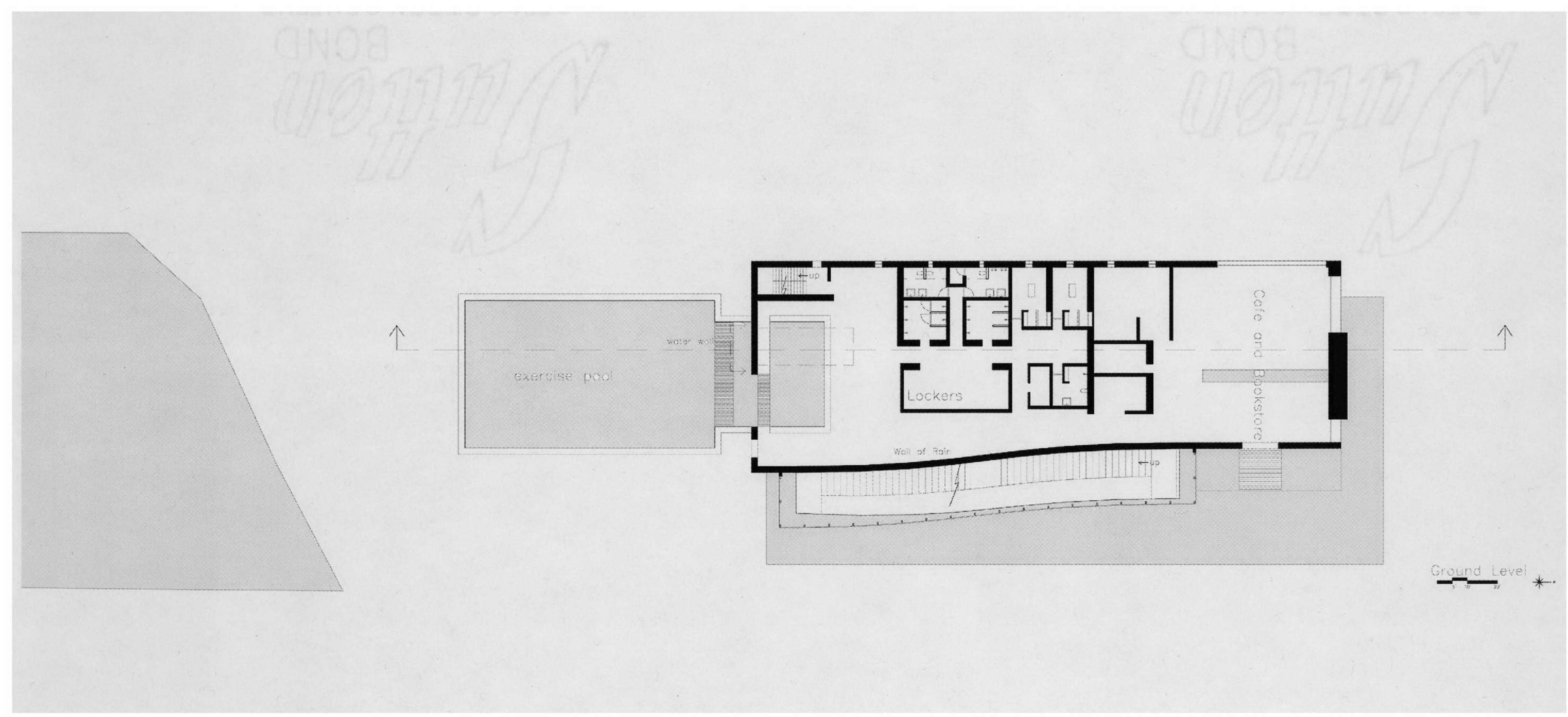

Figure 46 At ground level the spa is more public in nature. People may visit the pool, jacuzzi or café without visiting the upper levels. 


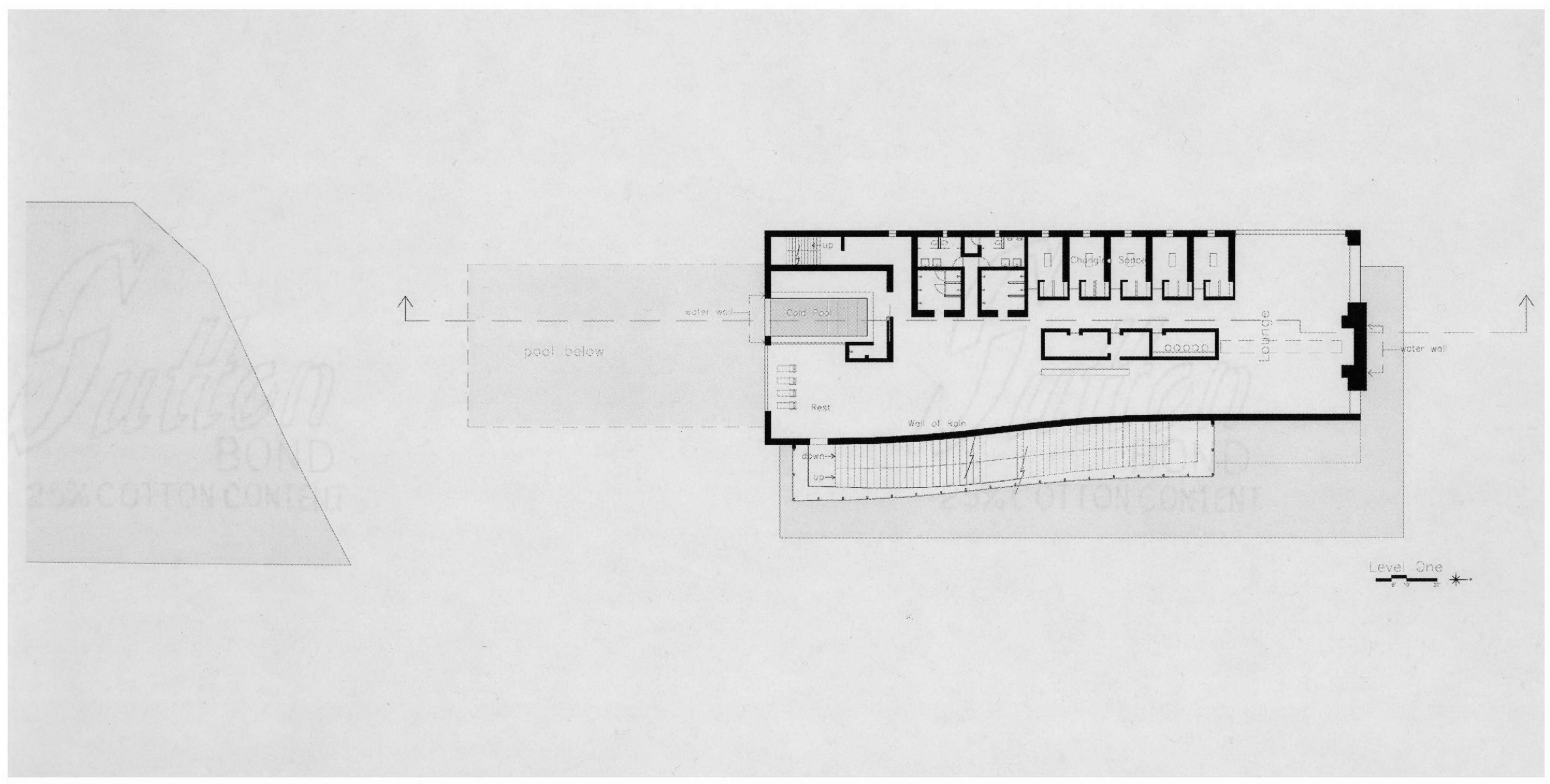


FLOOR PLAN, SPA LEVEL 2

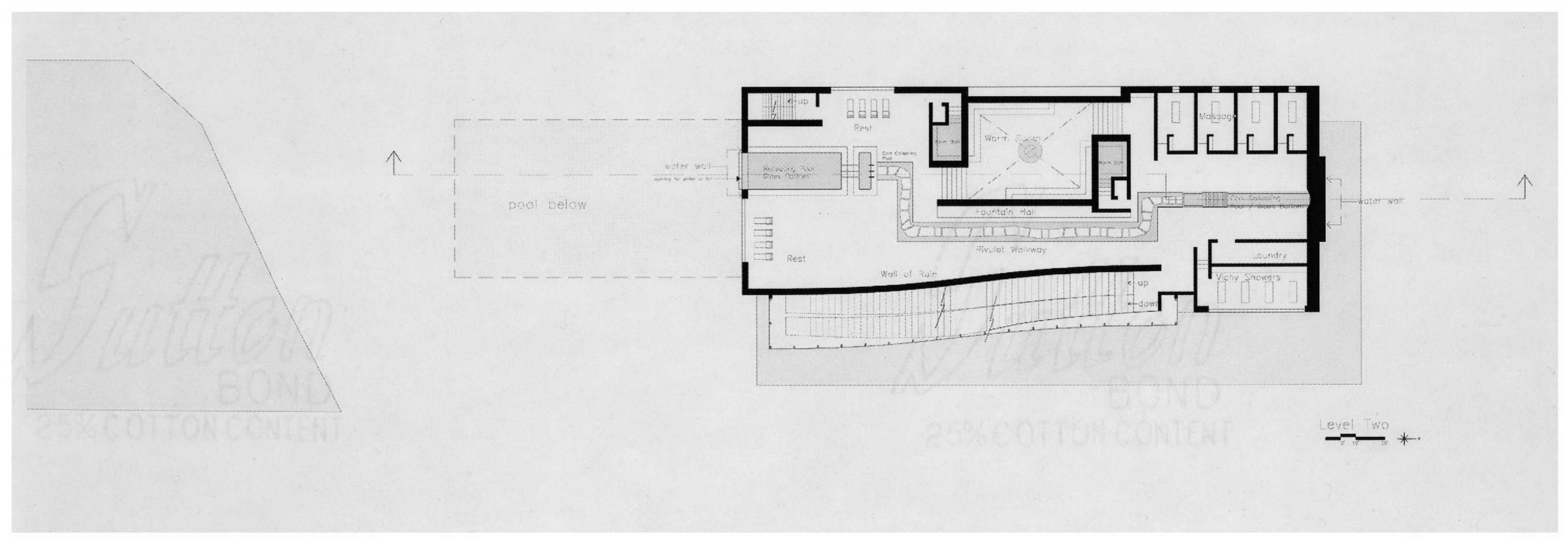

Figure 48 As one begins to ascend from the ground to the spa levels the stairs begin to narrow as a gesture towards an increased level of privacy. The primary feature of the warm level is the Warm Room, or sauna. Spaces for resting and massage are also available on this level. 


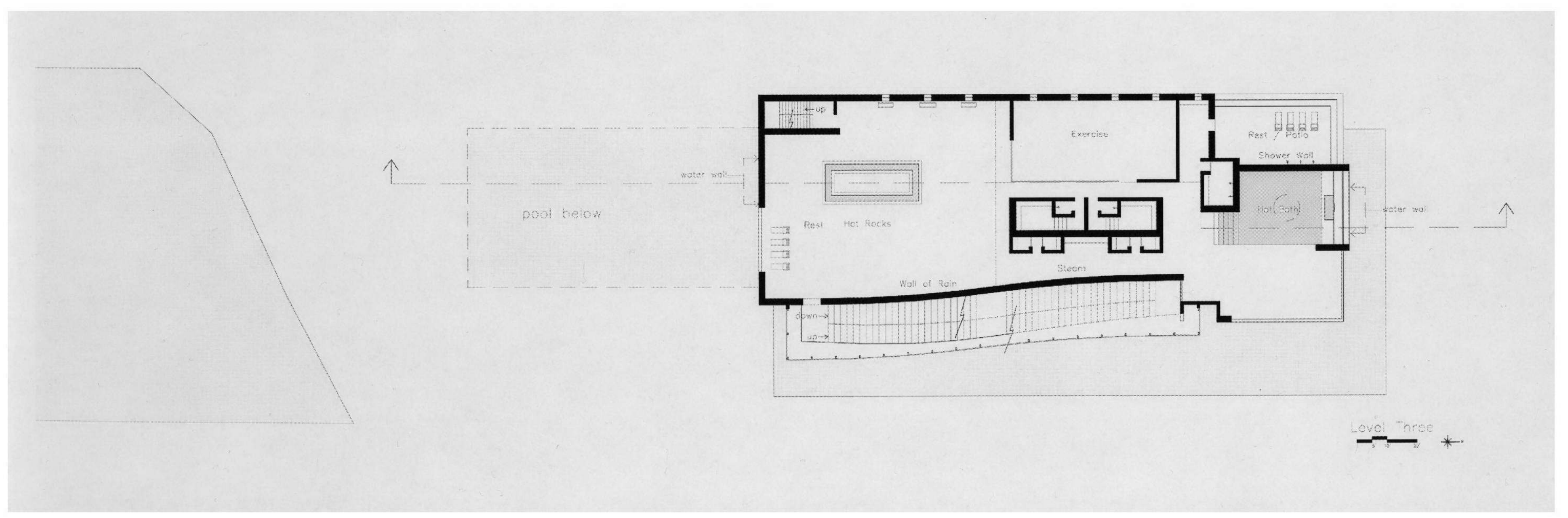

Figure 49 The third level of the spa is the hot level. The activities on this level include the hot bath, steam spaces, hot rocks and exercise. The hot level opens up to the sun and is partially outside. 


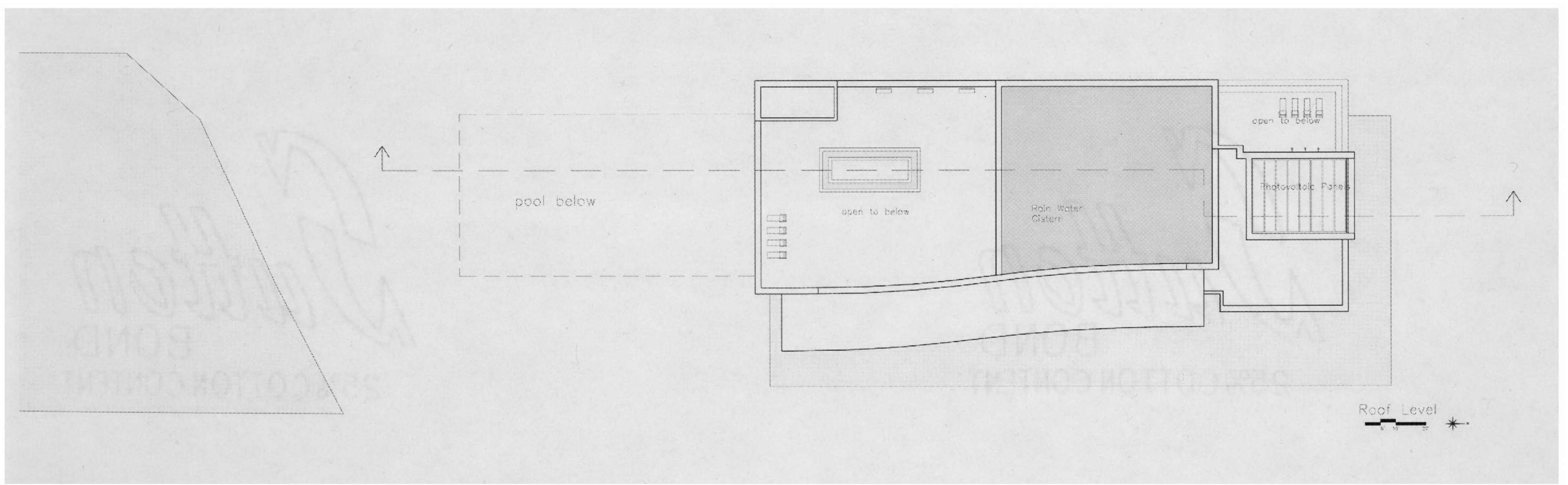

Figure 50 Rain merges with water from the water wall in a cistern on the roof where it is warmed by the sun. The

bottom of the cistern is painted black to facilitate the transfer of the sun's radiant energy. Solar collectors are located above the hot bath. 
in. 


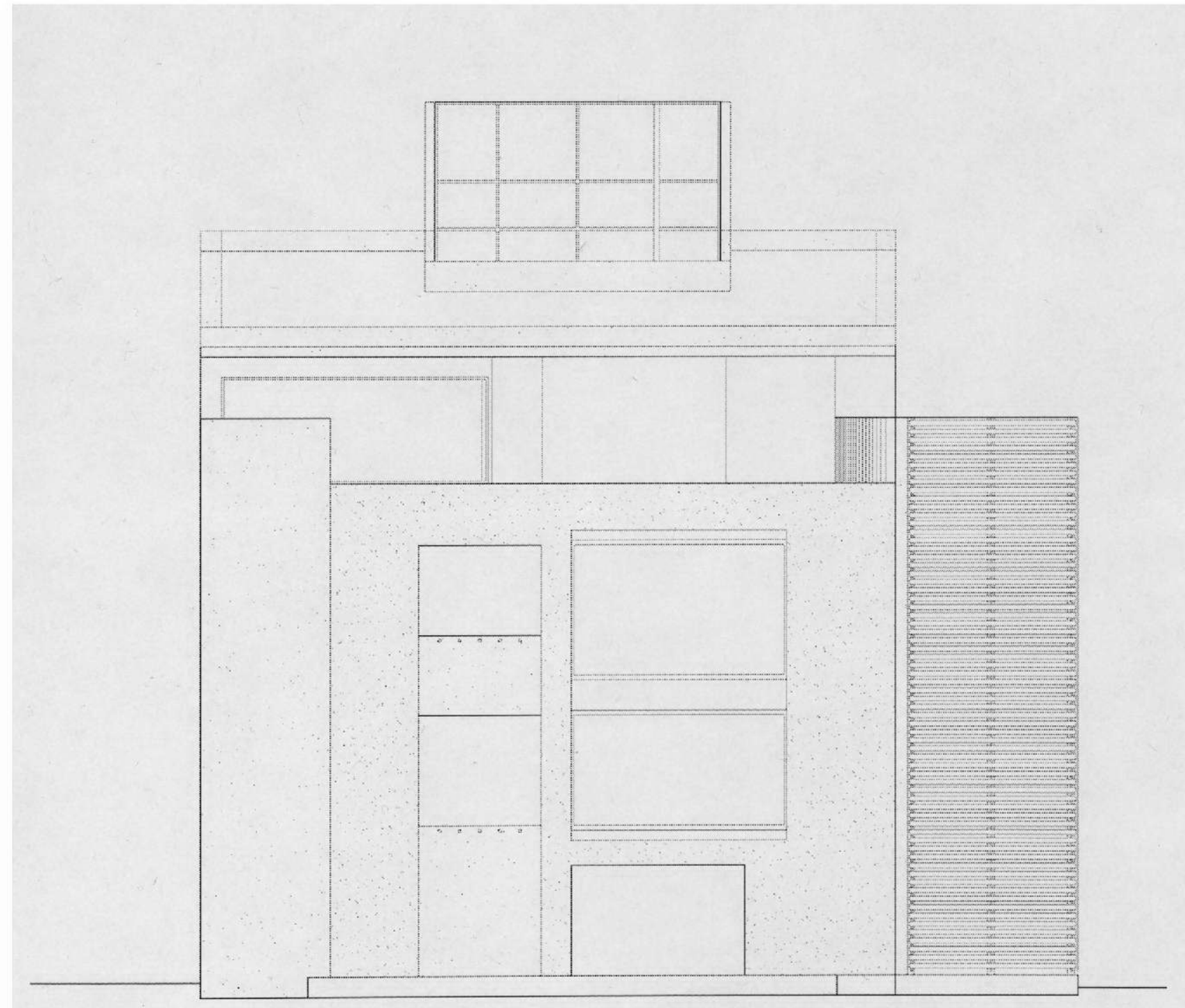

South. New River Elevotion

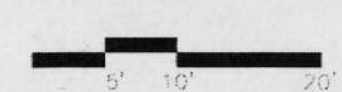

Figure 52 The south elevation faces the New River. A wall of water flows from the upper levels of the spa into the

exercise pool. 


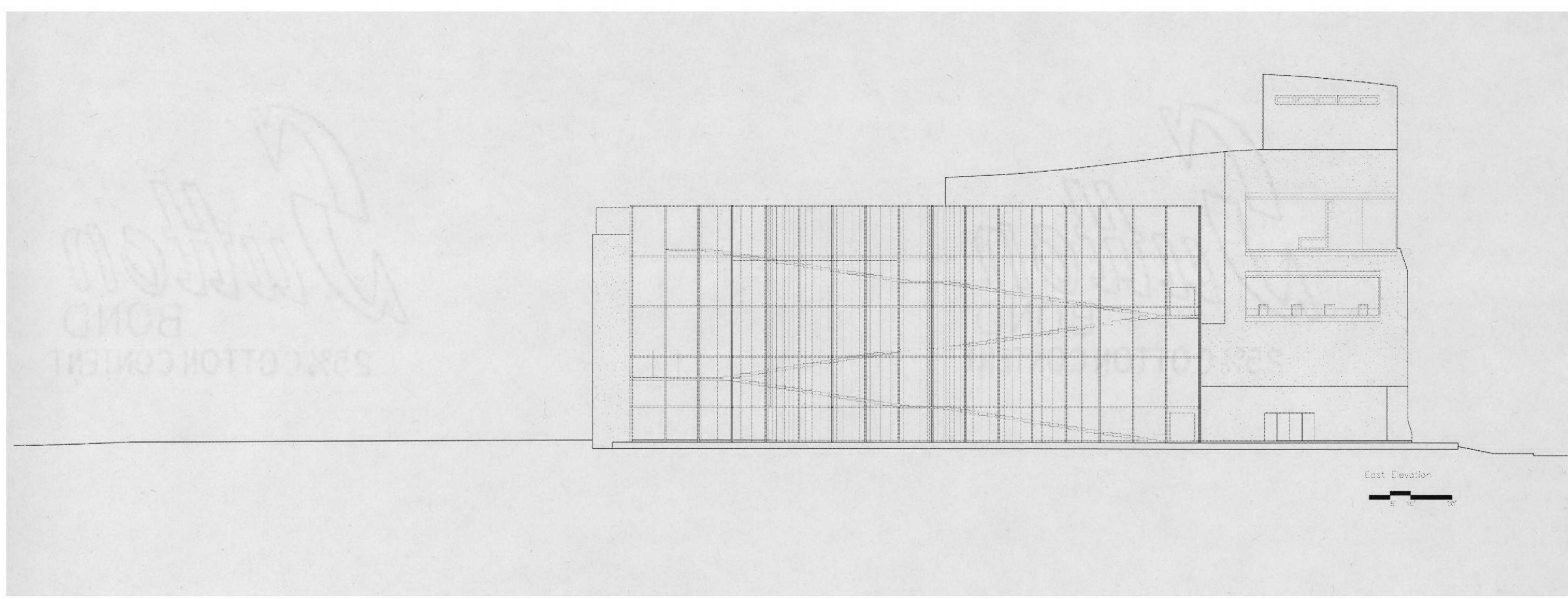


WEST ELEVATION

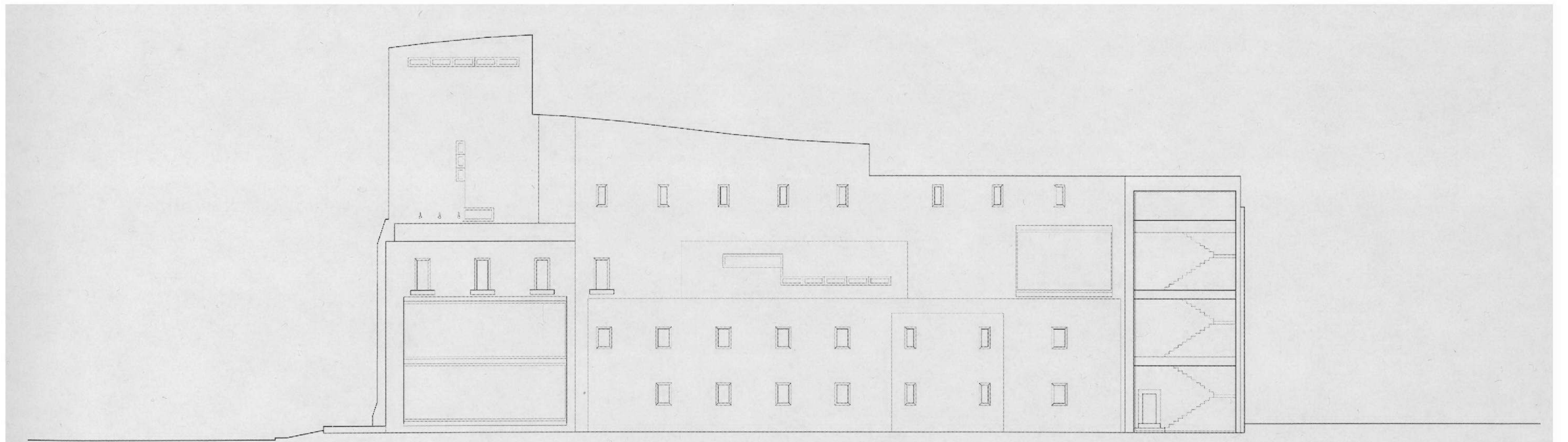

Los olos Bve

Figure 54 The west elevation faces a small road and a residential high-rise. The wall is designed to address the

conditions of the west side of the site. Features that it punctuates include: the outdoor shower wall and patio, the

exterior wall of the Warm Room, and the secondary staircase. 
LONGITUDINAL SECTION, WATER DIAGRAM

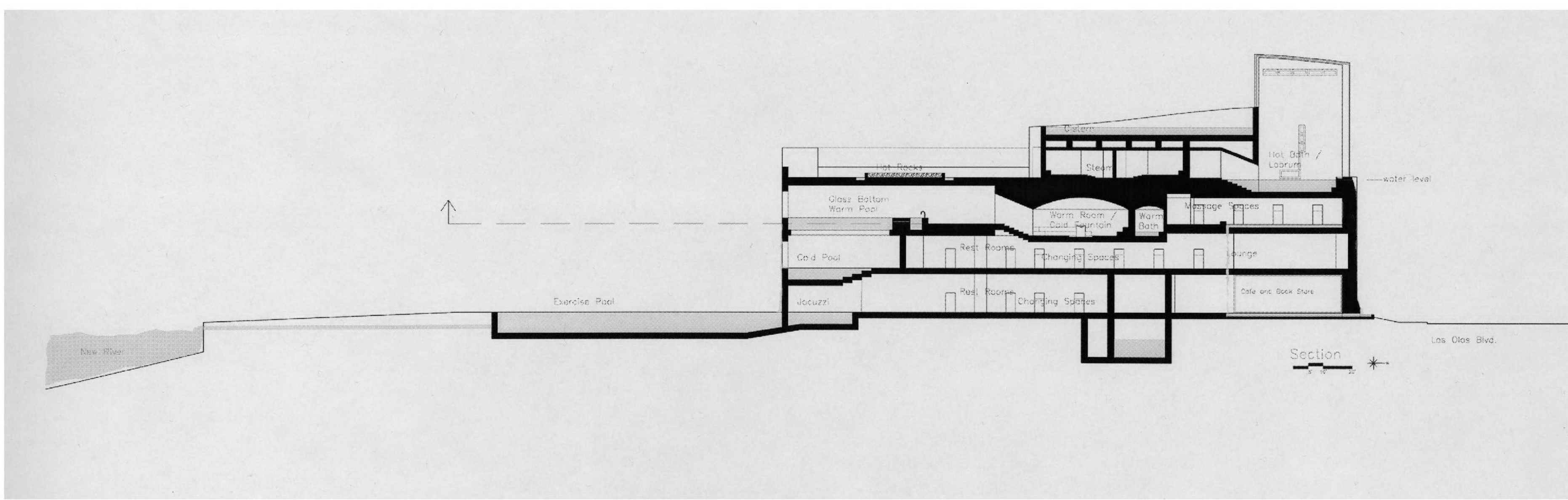

Figure 55 The longitudinal section depicts how the interior spaces have evolved. A water diagram is overlaid to help

with visualizing the water's presence. 


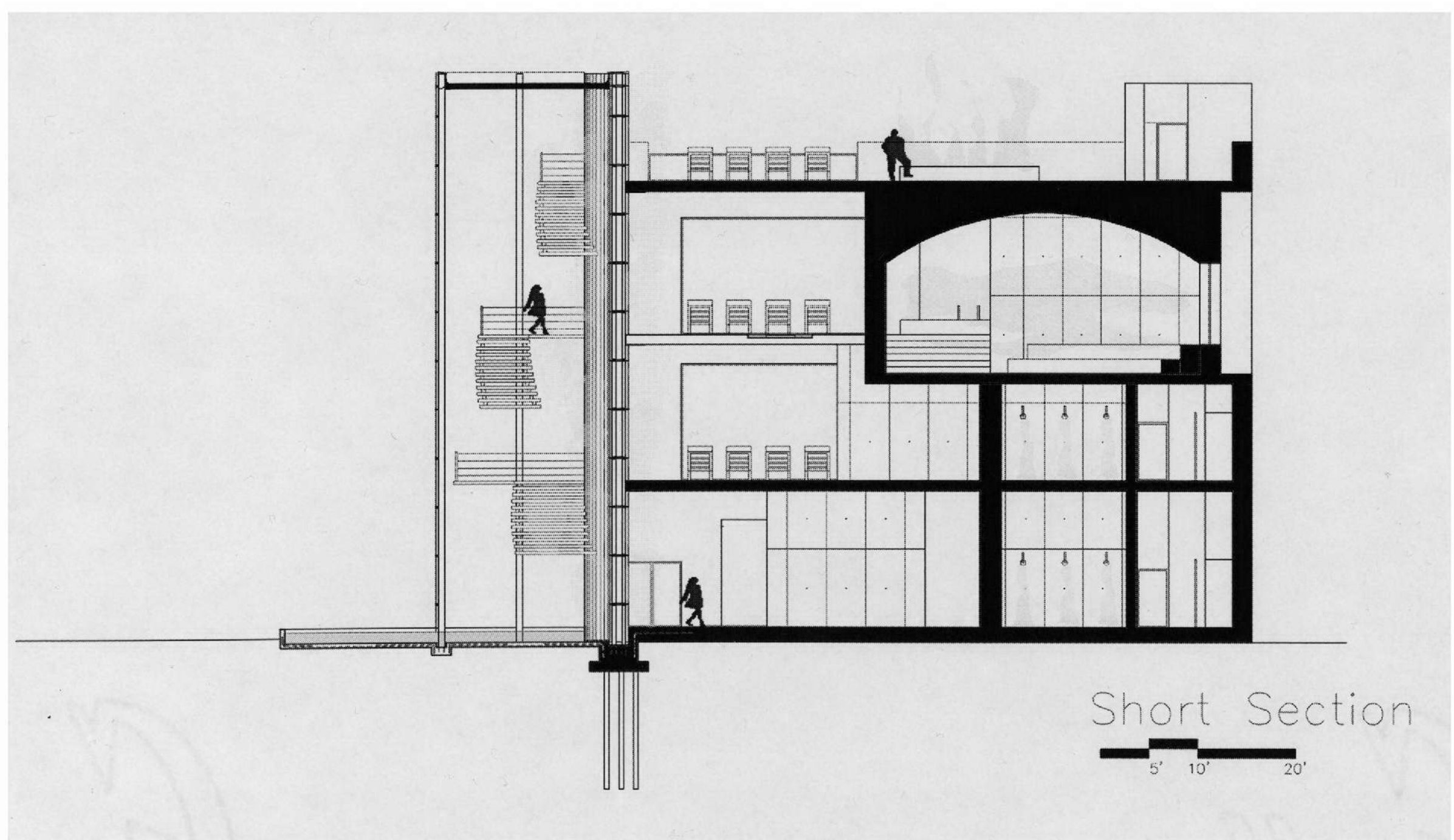

Figure 56 The short section reveals the stair enclosure and Wall of Rain, rest areas, showers and rest rooms, Warm

Room; and the hot rocks on the outdoor deck. A water diagram is overlaid to help with visualizing the water's

presence. 


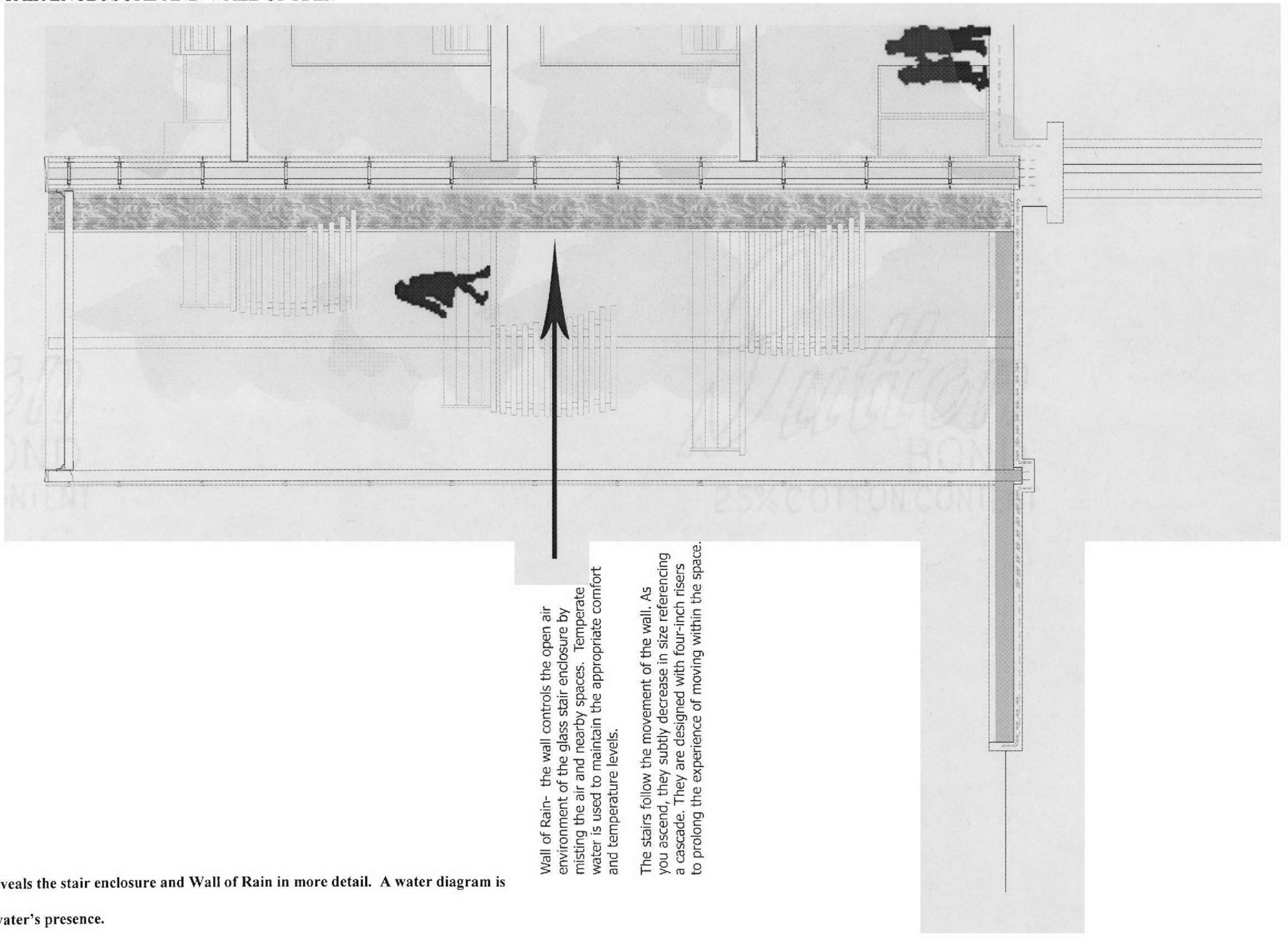

overlaid to help with visualizing the water's presence. 


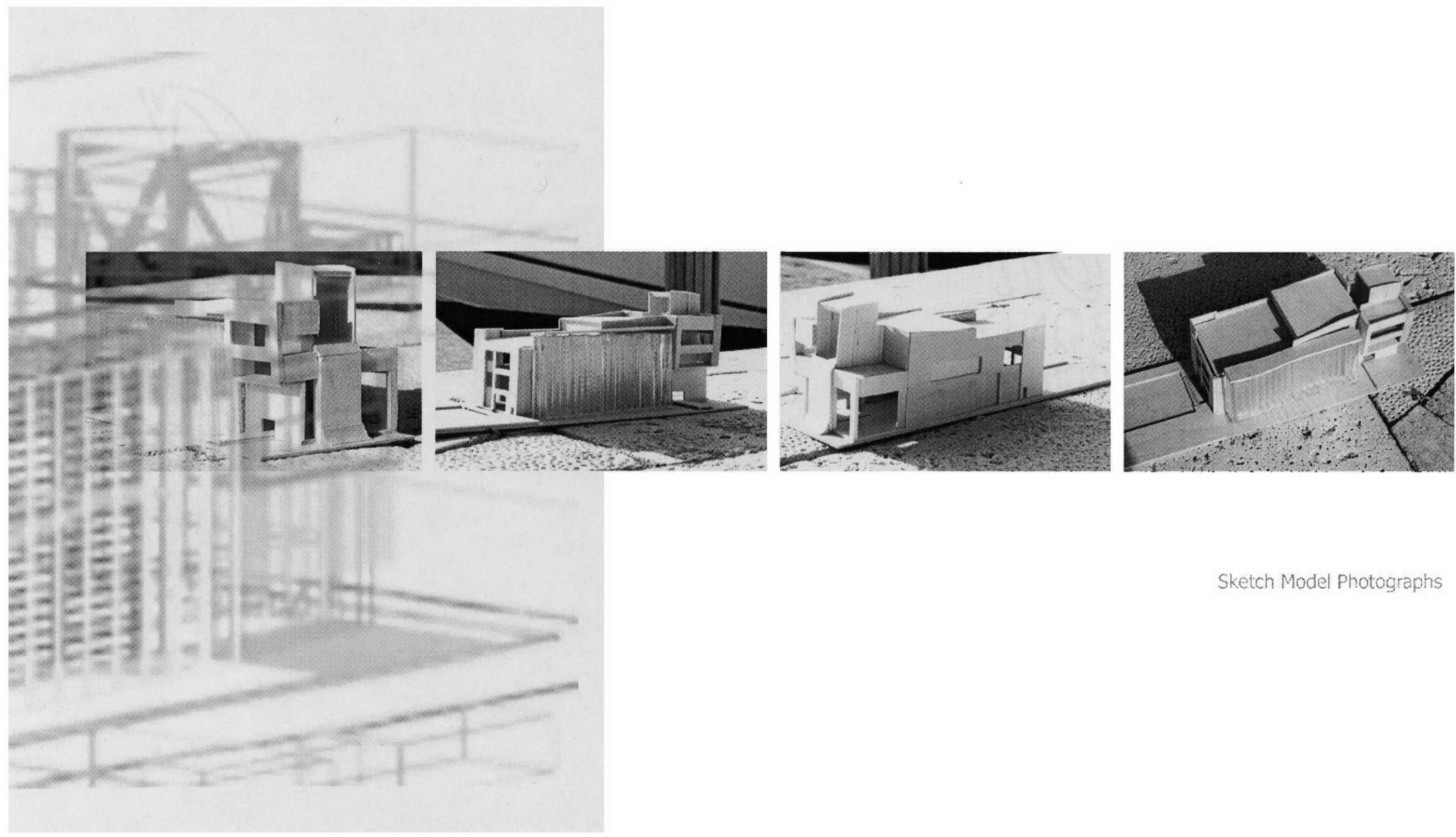



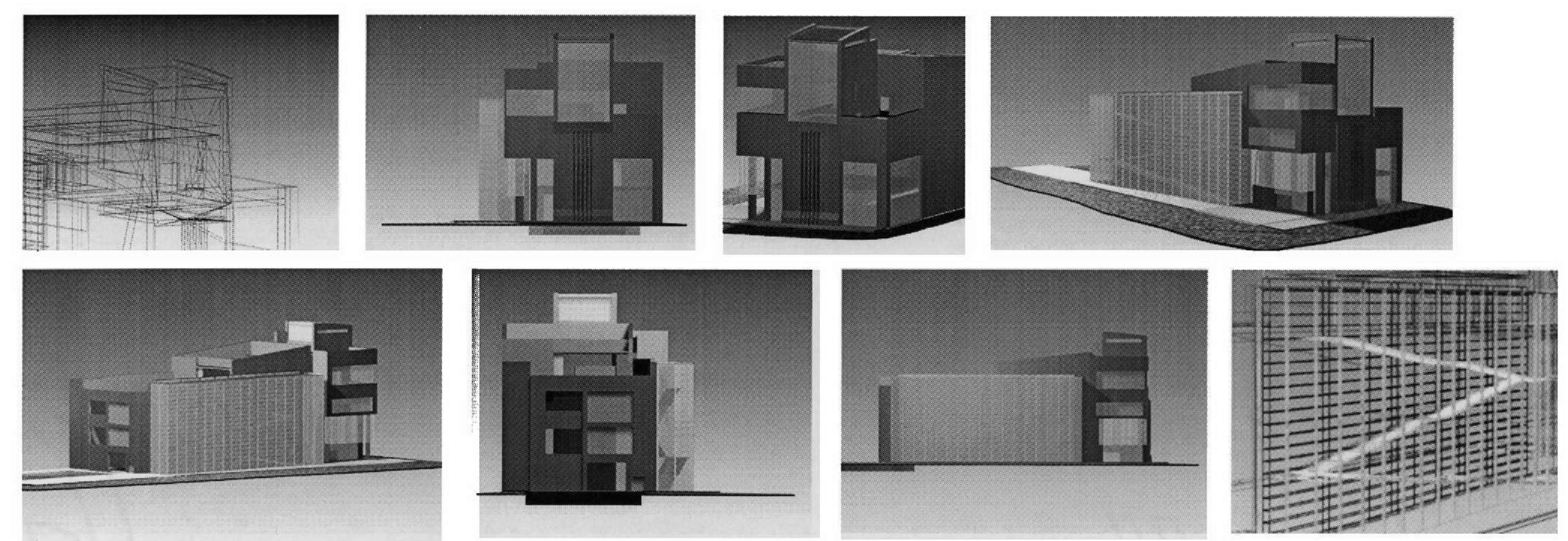

Computer Modeled Renderings 


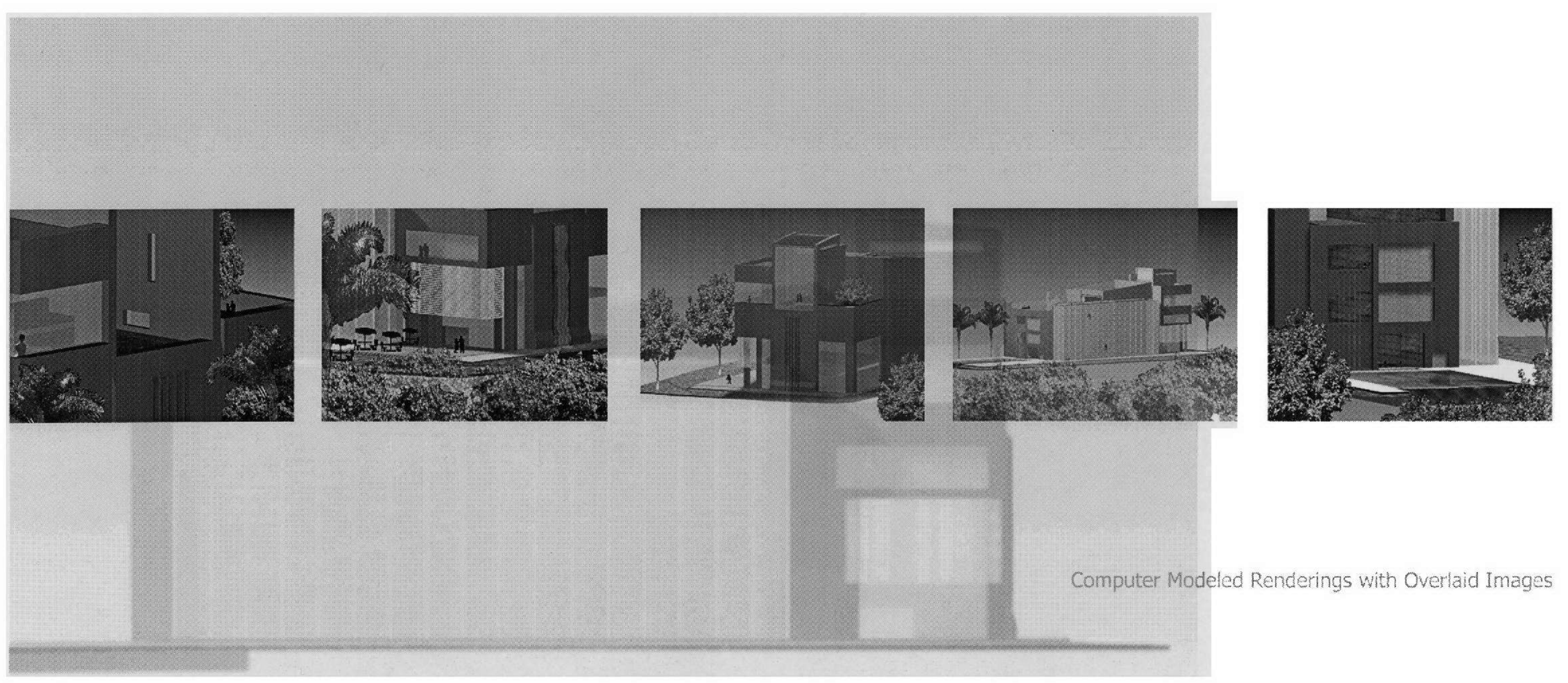




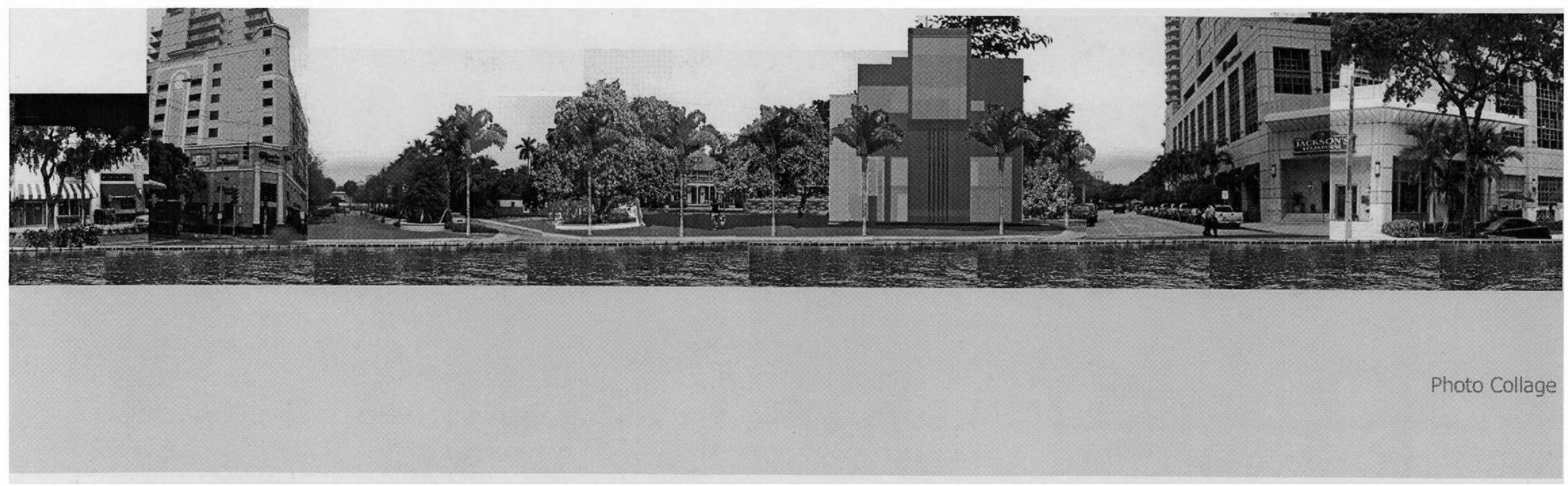



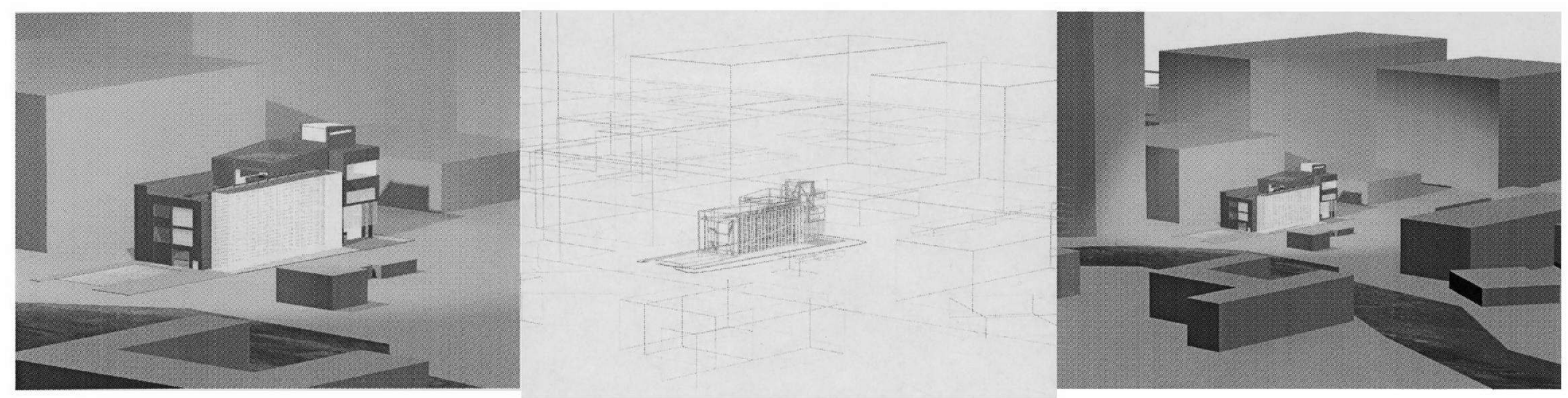

The Urban Spa, An Entrance to the River 


\section{CONCLUSION}

My project integrates architectural analogies, traditions established by the Roman bathhouse and technology of a modern spa, offering a sensuous interpretation of our water cycle.

In this thesis I have learned the importance of combining several types of research in order to generate ideas successfully and give meaning to a design. My thesis explores the parallel relationships between architecture and water. A thorough site analysis including the many ways it currently engages with and celebrates water lead to the topic. In architecture, these relationships exist as fountains, pools, rivers and oceans. They can be expressed naturally or as built form; and in many cases, conceptually. As I found in the case studies of Steven Holl and Lindy Roy, many building types are capable of expressing these relationships. By using the water cycle as a narrative for the project and by highlighting the importance of the water's source, my project not only becomes meaningful, but poetic and educational. As the design unfolds, the nature of the water cycle becomes the architectural equivalent of my project, The Urban Spa. As the narration of the water cycle evolves and the movement and temperatures of water begin to influence the design, the Roman bathhouse is introduced as another parallel. The traditions and sequence of activities combined with its program, allow the bathhouse to play an intimate roll in tying the project together in a way that can be experienced physically. 


\section{REFERENCES}

1. Leonard Pardue, Jessie Freeling, Leonard J. Greenfield and Patrick T. Gannon, Who Knows The Rain?: Nature and Origin of Rainfall in South Florida (Coconut Grove, Florida; Friends of the Everglades 1983)

2. Stanley David Gedzelman, Ph. D. "Water Cycle," Microsoft Encarta Online Encyclopedia 2003. http://encarta.msn.com. 1997-2003 Microsoft Corporation

3. Charles W. Moore, Water and Architecture (Harry N. Abrams, Inc. 1994)

4. Mary Ann Sullivan, The Fountain of Four Rivers, Piazza Navona http://www.blufton.edu/ sullivan/4rivers/4rivers.html. 2-05-2004

5. James Grayson Trulove ed. The New American Swimming Pool: Innovations in Design and Construction. (NY, Whitney Library of Design 2001) p.212

6. Fikret Yegul. Baths and Bathing in Classical Antiquity. (Cambridge: MIT, 1992)

7. Barbara McManus, The College of New Rochelle. Roman Baths and Bathing. July 2003 www.vroma.org/ bmcmanus/baths.html

8. Dan Cruickshank ed. Sir Banister Fletcher's: A History of Architecture, Twentieth Edition (Oxford: The Royal Institute of British Architects and The University of London, 1996)

9. Michael J. O'Connor, Down on the Delta p.44-45.

Richard Ingersoll, Between Typology and Fetish p. 80-89

Architecture Magazine, March 1999

10. Fernando Márquez Cecilia and Richard Levene eds. El Croquis: Steven Holl 1986-2003 (US, Idea Books 2003)

11. ROY website, Projects. www.royarchitecture.com

Poolhouse, Sagaponac, New York, 2000-.

Okavango Delta Spa, Okavango Delta, Botswana, 1997-

12. Thomas Van Leeuwen, Helen Searing ed. The Springboard in the Pond: An intimate History of the Swimming Pool. (The MIT Press Cambridge, Massachusetts 1998)

13. Coral Gables Venetian Pool: An Historic Treasure In The City Beautiful. www.venetianpool.com. 